
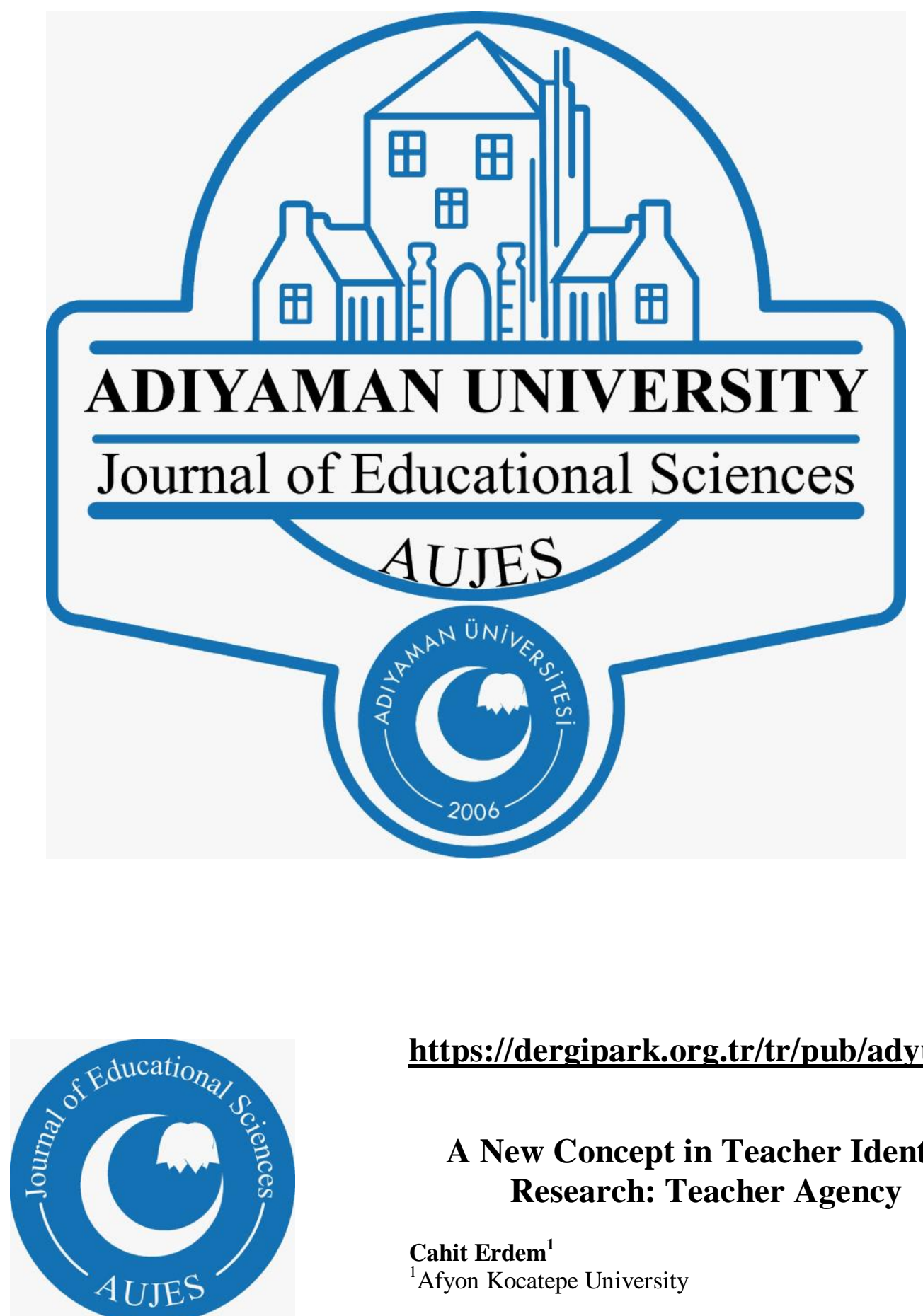

https://dergipark.org.tr/tr/pub/adyuebd

A New Concept in Teacher Identity

Research: Teacher Agency

Cahit Erdem ${ }^{1}$

${ }^{1}$ Afyon Kocatepe University

ADIYAMAN UNIVERSITY

Journal of Educational Sciences

(AUJES) 
Erdem

\section{To cite this article:}

Erdem, C. (2020). A New Concept in Teacher Identity Research: Teacher Agency. Adiyaman Univesity Journal of Educational Sciences, 10(1), 32-55. 



\title{
A New Concept in Teacher Identity Research: Teacher Agency Cahit Erdem ${ }^{*}$ \\ ${ }^{1}$ Afyon Kocatepe University
}

\begin{abstract}
Teacher agency, considered as an element of teacher identity, has become a concept upon which studies have elaborated recently. However, academic research studies on this concept carried out in Turkey is highly limited. Indeed, there is not a consensus even on the Turkish equivalent of the concept. In this study, in which 'ögretmen etkenliği' is adopted, the issues of Turkish meaning of teacher agency, its relation with teacher identity, emergence of the concept and its definitions, its theoretical foundations, characteristics of agentic teachers, related areas of research such as educational changes and professional development, and research studies on teacher agency carried out in Turkey are elaborated on based on an extensive literature review. In addition, in the conclusion, how teacher agency can be developed is discussed in the contexts of arrangement of teachers' work contexts, in service training and pre-service teacher education. With this study, it is aimed to offer a comprehensive source about teacher agency in Turkish to form a basis for future studies to be carried out in Turkey.
\end{abstract}

Key words: Teacher Agency, Curriculum, Professional Development, Agentic Teacher

\section{Introduction}

Educational research is carried out to answer local and global educational issues and problems, and research trends may tend to different methods and topics. Studies concentrate on certain areas due to reasons such as emergence of new concepts and new necessities or scientific trends. Teacher identity has become one of such areas recently. In the international literature, studies on teacher identity have gained pace particularly since 1990s (Beaucham \& Thomas, 2009; Beijaard, Meijer \& Verloop, 2004). Teacher identity, which is how teachers define themselves to themselves and others as teachers (Lasky, 2005), is affected by factors such self, reflection, emotions, past experiences and contexts (Beauchamp \& Thomas, 2009), and it is a complex and dynamic balance process between teachers' self-images and social roles (Volkmann \& Anderson, 1998). Indeed, teacher identity can be expressed as teachers' dedication of being a teacher as they have wanted to be (Buchanan, 2015). When the facts such as teachers are the most significant factor on students (Darling-Hammond, 1997), the quality of a school cannot pass beyond the teachers' quality (Kavcar, 1987), and teaching profession has a social aspect as well as professional aspect are considered, teacher identity arises as a significant quality that needs to be highlighted.

Beijaard et al. (2004) carried out an extensive literature review on teacher identity, which is hard to define because it has a complex structure regarding the self as well as its social aspect, it transforms in the course of time from pre-service teacher education period to different phases of teaching career, and it is affected by contextual factors, and argue that it has four sub-dimensions. They suggest that teacher identity a) has an ever-changing and dynamic structure; b) it is affected by contextual factors; c) it has sub-identities; d) it involves teacher agency. This study dwells on teacher agency concept on which great emphasis has been paid in the international literature and respected journals published special issues but which was ignored in Turkey until a few years ago. Teacher agency is a basic and indispensable part of identity formation and development (Allen, 2018; Parkison, 2008; Tao \& Gao, 2017). In the current study, the emergence of the concept, definitions and theoretical bases, characteristics of agentic teachers, related study areas and studies carried out on this topic in Turkey are put forth. To this end, an extensive review of national and international literature is carried out and after this review; it was aimed to be introduced to Turkish literature in all aspects. This way, the attempt was to draw attention to teacher agency concept and offer a Turkish resource to be a reference for future studies.

\footnotetext{
* Corresponding Author: Cahit Erdem, cahiterdem@gmail.com
} 


\section{Teacher Agency \\ Turkish equivalent of the concept}

As Turkish equivalent of teacher agency, "öğretmen etkenliği” is adopted in this study. In Merriam-Webster dictionary, agency is defined as "the capacity, condition, or state of acting or of exerting power". Yaylı (2017) used "öğretmen etkinliğii", Bellibaş, Çalışkan and Gümüş (2019) used "öğretmen failliğii", Ataş Akdemir and Akdemir (2019) used "öğretmen aktörlüğ̈̈" for teacher agency. In a current report published by "Teacher Network", it is used as "state of being a subject" (Ayan, 2020). Turkish Language Association (2019) defines "etkin" as working, active, "fail" as someone who is acting an act, "aktör" as someone who has an effect or contribution in an act, and "özne" as someone who performs an act. "Etken" is defined as something/someone affecting, factor, something exerting change on something, active and antonym of passive. The term "etken" is preferred as a more comprehensive term because theoretical basis of teacher agency suggests that it is related to capacity of acting, considers teaching as a profession requiring taking initiatives rather than being a technician, teachers' approach to implementing central policies is important and it affects social contexts as well as it is affected by them. Teacher agency refers to teachers' capabilities of acting in line with their own goals including getting beyond the rules and regulations present in their contexts (Oolbekkink-Marchand, Hadar, Smith \& Helleve, 2017).

\section{Emergence of the Term and Definitions}

Priestley et al. (2015), who made important publications on teacher agency, explained why teacher agency is needed by evaluating the education policies applied worldwide, the role of teachers in these issues and what is expected from teachers. Accordingly, the approach, which includes the development of highly structured curricula, strict control, and designing contents of curricula and teaching methods through the central administration, has been abandoned in recent years. This approach prevented teacher professionalism. Implementation of a teacher-proof curriculum causes undesired outcomes and implementation gap because teachers often act in contrary to goals when they do not adopt the situation (Priestley et al., 2015). The Turkish education system has also been in a change and transformation for many years. Although there is a continuous reform effort in many fields such as curricula, schooling levels, transition systems, teacher training and employment processes, and the teaching materials used, the realization of change efforts depends on teachers and, it is impossible to transfer the changes that are not adopted by teachers to the class as stated in the "Teacher Strategy Document" (Erdem \& Eğmir, 2018). Teachers can be considered as a bridge between official curricula and enacted curricula. The extent to which the official curricula will be implemented depends on the teachers.

In international literature and practices, three basic educational policies have been implemented in the context of the role of the teacher in the implementation of the educational policy (Priestley et al., 2015):

1. In some countries, teachers are positioned as the main actors of change and teachers are actively involved in curriculum development. Program reforms carried out in recent years in Scotland and the Republic of Cyprus can be evaluated within this scope.

2. The second trend includes policies to improve the quality of teachers through continuous professional development activities. Professional learning communities, new teacher standards and the requirements of teachers to receive postgraduate education can be evaluated within this scope.

3. The third trend that has increased in recent years contradicts the first two trends and affects these developments negatively. The third trend is to use accountability systems and criteria to measure educational effectiveness in many countries. By placing the teacher at the center of the educational processes, the first two trends try to eliminate the ever continuing strict curriculum approach which goes from the center to the local and excludes teachers while the last trend attempts to eliminate teacher autonomy.

The strict determination of the content from the center has started to be replaced by school audits and the evaluation of the success data, and the arrangements to prioritize the educational outcomes (Kuiper et al., 2013). This latest trend has done more harm to teacher autonomy than the central curriculum approach (Biesta, 2004; Priestley et al., 2015). This performance-based approach creates a culture of competition at school, pushing teachers to show a showy performance to make a good impression on the outside, and this can even lead to unethical actions such as corruption or cheating (Ball, 2003; Keddie et al. 2011; Priestley et al., 2015; Sahlberg, 2010). This situation also causes great pressure on teachers and can negatively affect teachers' stress and burnout levels. The teacher performance system that is considered to be implemented in Turkey can be regarded as part of this trend.

The vital role of teachers in the implementation of educational policies and reforms, the weakening of central education policies and the increasing attention to local conditions, and academic research on teacher 
identity brought the concept of teacher agency to the fore. This has been thanks to the understanding that the teachers affect the educational conditions only when they show desire and skill, that is, when they are agent (Kayi-Aydar, 2015). In this context, teacher agency has emerged as a concept in understanding how teachers take action and how they interact with policies, but there are also important problems in defining the concept (Priestley et al., 2015).

First, it would be useful to define the concept of agency. According to Giddens (1984), agency is the ability of the individual to make changes in pre-existing work or actions. In parallel, agency can be defined as the degree to which the person feels control of his actions (Beijaard, 2009). Roger and Wetzel (2013) see agency as the capacity of individuals to take action in a purposeful and reflective way in their lives, but Emirbayer and Mische (1998) consider agency not as a capacity but as something acquired in contextual conditions. Agency consists of an individual's past lives, wishes and expectations for the future, and actions they take by interacting with the context at the time they are in (Emirbayer \& Mische, 1998).

The concept of teacher agency is based on the philosophical, psychological and social psychological foundations of the concept of agency in psychology (Paris \& Lung, 2008). Teacher agency is a dynamic process that is shaped by factors such as teachers' beliefs, personal goals, curriculum and pedagogy knowledge (Tao \& Gao, 2017). Oolbekkink-Marchand (2017), who defines agency as the capacity to engage in purposeful actions involving desire, autonomy, freedom and choice, defines teacher agency as the ability of teachers to go beyond the contextual rules and regulations and act based on their own goals. Agency is not something that people have, but it is what they do (Priestley et al. 2012), in other words, action is at the forefront. Teacher agency is defined as the active contributions of teachers to shape the work they do during the teaching process and the situation they are in (Biesta et al., 2015). Through these active contributions, teachers aim to both increase their own learning and enable students to learn best in their classrooms (Pyhältö, et al., 2012).

Teacher agency has been addressed in terms of responding to educational changes or professional development. Particularly how teachers react to changes in curricula or educational policies is examined in this sense. Teacher agency includes taking action and even resisting in new and creative ways to overcome the norms and regulations when the norms and regulations that teachers are expected to comply with are not professionally appropriate (Toom, Pyhaltö, \& Rust, 2015). It is expected that an agentic teacher will react differently, taking into account the characteristics of the context in which one is located and one's own goals. Teacher agency can occur at different levels, from fully adapting in the context of educational changes to resilience or moderate approach (Tao \& Gao, 2017). The reason for this situation is that teacher agency also differs from individual to individual. Teachers' past experiences and working contexts are different (KayiAydar, 2015).

Agency is also important for teachers' professional learning. Teacher agency is much more than coping with difficult situations. Agency requires a development-oriented mind structure (Allen, 2018). Pedagogical competence and expertise are also needed to make positive changes in students' lives (Anwaruddin, 2017). In the context of professional development, teacher agency is defined as the ability and initiative of teachers to manage their own professional development and contribute to the development of their colleagues (Allen, 2018). Agency is a tool to guide one's teaching career and to stay true to oneself during this process (Ketelaar et al., 2012). Teacher agency is part of a complex dynamic intertwined with the structural and cultural features of school, national education and broader national policies (Mifsud, 2018, p.194). Structural and cultural characteristics of society and school affect teacher agency and are affected by teacher agency. Each action or decision taken by the teacher is influenced by past experiences, the context in which they exist and the conditions that will affect future actions (Lasky, 2005).

\section{Structure of Teacher Agency}

In the process of teachers' policy implementation, teacher agency is an important concept. The ecological model put forward by Priestley et al. (2015) has been the most accepted framework in the literature. The ecological model put forward for teacher agency suggests that the agency capacity of the teacher and the conditions of the context in question shape the agency of the teacher. According to this model, agency is a developing phenomenon, not a capacity or feature in individuals (Priestley et al., 2015). According to Biesta and Tedder (2007), agency occurs as a result of the joint interaction of individual efforts and existing resources, contextual and structural factors. For this reason, agency is not a feature that individuals have, but a phenomenon achieved; in other words, it is not an attribute of the actors, but an attribute of the interactions of the actors with the context in which they perform the action (Priestley et al., 2015). The ecological teacher agency model is based on Emirbayer and Mische's (1998) theories on the concept of agency studied in psychology. Reaching agency is related to three basic dimensions. Agency arises from the effects of the past, future projections and the interaction between the time and the context (Priestley et al., 2015). Accordingly, agency depends on the 


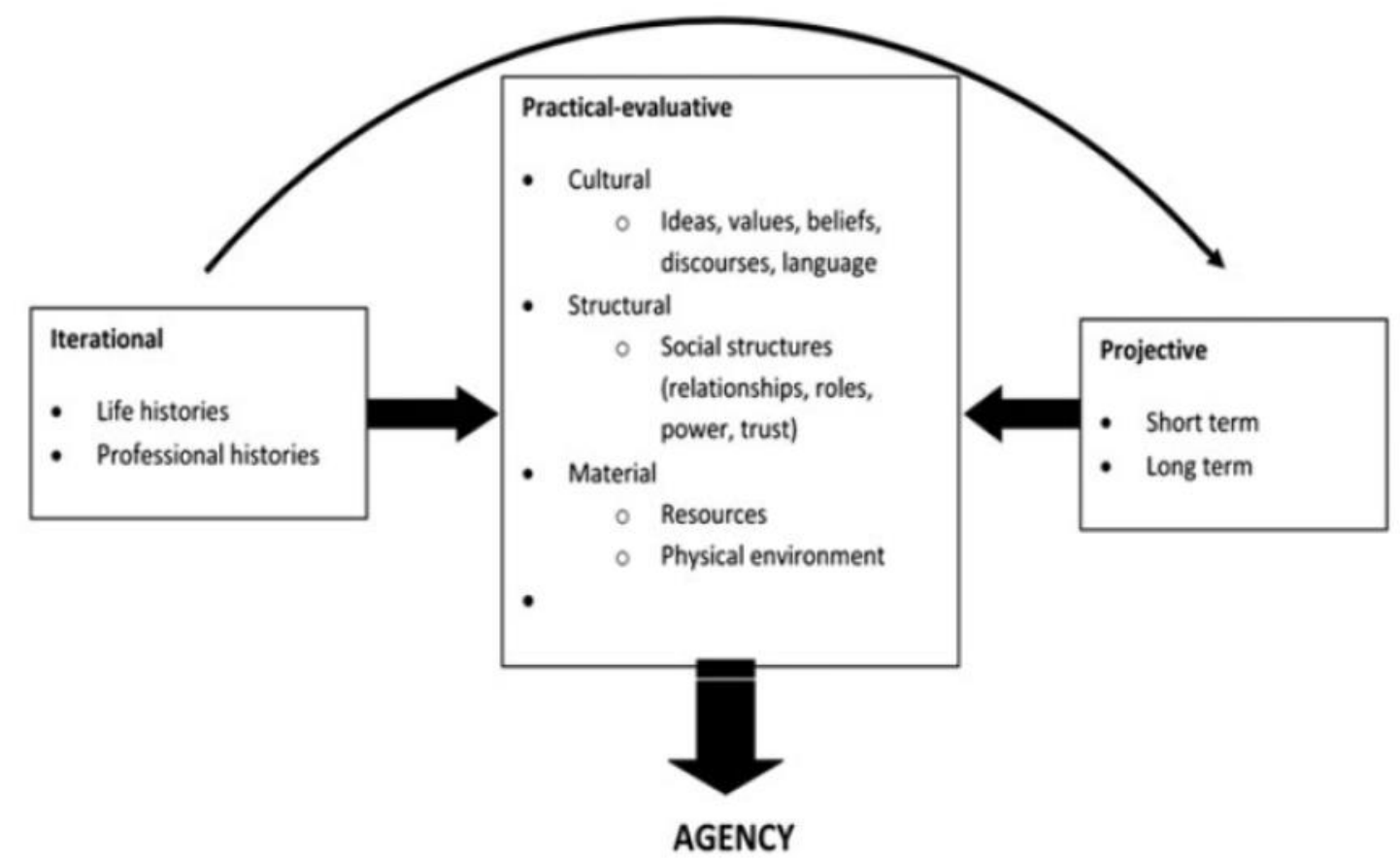

temporal factors and is in close relationship with the context. The ecological model of teacher agency, which includes these three dimensions, is given in Figure 1.

Figure 1. Ecological model of teacher agency (Priestley et al., 2015)

According to the model, teacher agency consists of iterational, practical-evaluative and projective dimensions. The features of this model are described below based on the work of Priestley et al. (2015).

The iterational dimension is related to the teacher's past experiences. In this dimension, a distinction is made between the individual life stories of teachers and their professional backgrounds. The professional background includes both teachers' own education as a teacher and their teaching experience. The point to be noted here is that teachers choose from the repertoire of past actions and thoughts according to the model. Rather than habits, the teacher chooses the ones that suit her/his needs from his previous experiences while dealing with the current problems and runs it in her/his current practice. These experiences are also effective in generating projections for the future. In this case, it is possible for teachers with richer past experiences to react to existing problems in a variety of ways and to develop a broader perspective on the future. In this context, both individual and professional background experiences of teachers are important for teacher agency.

The projective dimension is about the future. This dimension includes the short- and long-term prospects and expectations of teachers in the context of their professions. These wishes and expectations created by teachers can be completely positive, and teachers may tend to strive for the development of students, the school and themselves. On the other hand, these requests may be negative or there may be instrumental requests such as saving the day or covering up the negativities. Regardless of what type of expectations and aspirations for the future, and whatever purpose lies behind them, these aspirations are based on teachers' values and beliefs as well as past experiences.

The practical / evaluative dimension is related to the time that teacher is in. Although agency is related to the past and the future, it is exhibited at the current time. In this dimension, a distinction is made in terms of cultural, structural and material aspects. These elements form the existing context that provides the conditions and possibilities that teachers acquire agency. These conditions and possibilities are both application-oriented and also evaluative. In this context, there are various options for teachers to act in response to the demands, dilemmas or uncertainties that they face in their context. Among these options, the capacity to reach practical and normative judgments and take action determines agency.

According to this model, achieving efficiency is always affected by past experiences. It is influenced by future trends in a common ground of short and long term goals and values. Agency always takes place in a concrete environment. Therefore, it is limited and supported by the cultural, structural and instrumental resources of the actors (Priestley et al., 2015). 
The ecological approach predicts that teacher agency cannot be considered separately from the context in which teachers work (Biesta et al., 2015; Jenkins, 2019). In this approach, teachers are not actors acting in an environment, but those who take action through that environment, and the teacher's action is actually a reaction to that environment (Biesta \& Tedder, 2006, Jenkins, 2019; Priestley, Biesta \& Robinson, 2016). On the other hand, environmental conditions are diverse. Complex and rapidly changing school environment, the approach of the school administration to program changes, especially the role of principals and peer relationships are included in this scope (Jenkins, 2019).

Jenkins (2019) introduced a teacher agency model in order to determine the complex structure of teacher agency, monitor it from the beginning and reveal the contextual factors affecting it. This model, which is based on the model of Bandura's triadic reciprocal causation model and the basic concepts of agency, is named as the Triadic Reciprocity Framework Core Agency Concepts (TRFCAC). The TRFCAC model is presented in Figure 2.

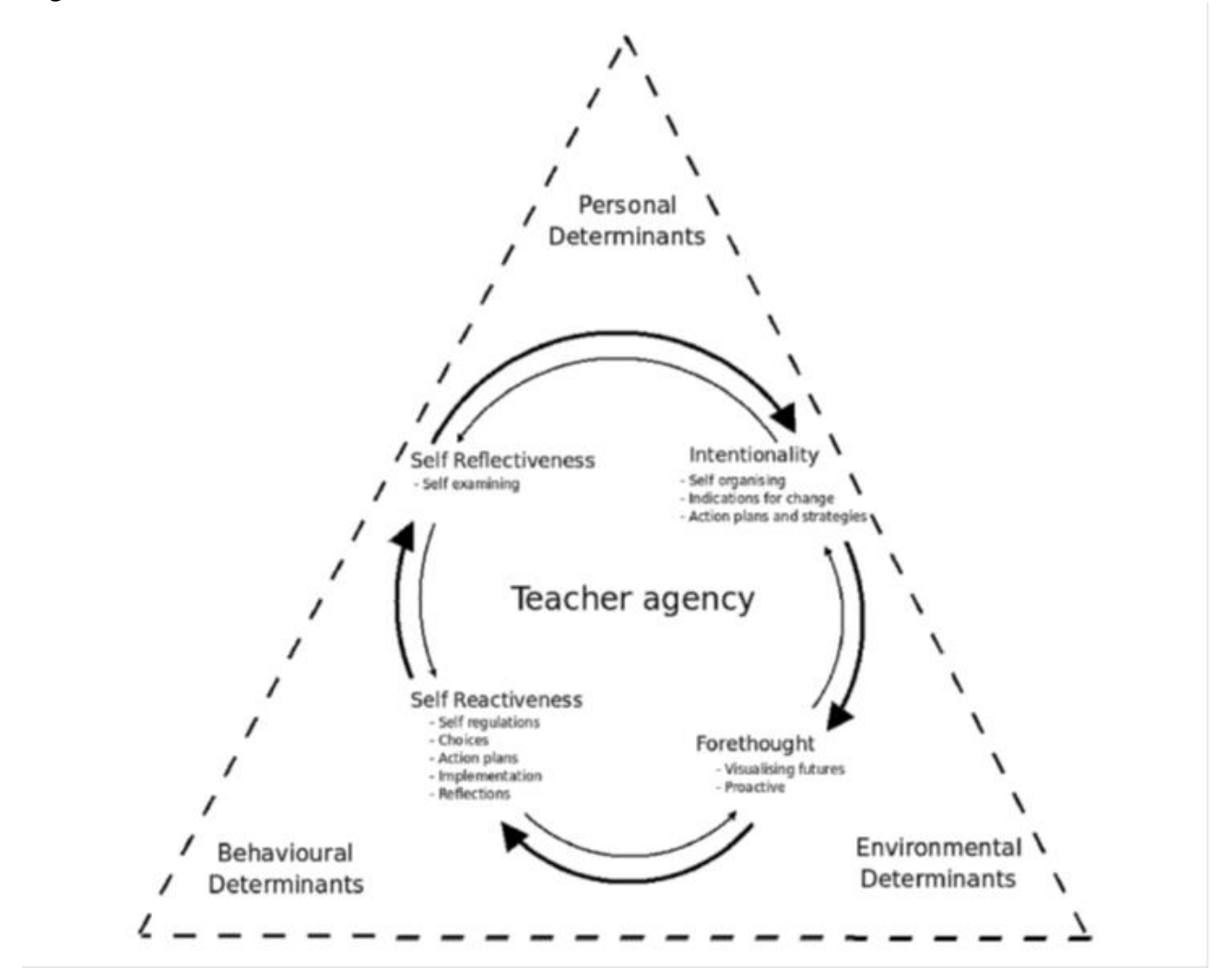

Figure 2. Jenkins's TRFCAC model (Jenkins, 2019)

This model is about understanding teacher agency in the process of curriculum changes or revisions. According to this model, teachers are producers of experiences and affect events. They strive to influence the things they could influence so that future events meet their expectations and that unwanted actions do not take place. Actions in this context are also affected by three factors that are related to each other. These factors are personal, environmental and behavioral factors. Relationships between contextual factors are constantly changing in terms of pressure and influence. In other words, teachers can be both the subject and the agent of change.

\section{Characteristics of Agentic Teachers}

While the definition and structure of teacher agency are included in the literature, the characteristics of the agentic teachers are also explained. First of all, it should be stated that the agentic teachers are teachers who can take the initiative for their own purposes. This initiative may also require going beyond the rules of the school and education system. The factors that push the teacher to this situation may include beliefs about learning, past experiences, expectations from the future, moral sense of responsibility and prioritizing student success. On the other hand, the most important dimension for agency is taking action. The teacher tries to shape his environment through these actions and as a result, students are expected to make the best use of education and training. In this case, some of the characteristics of agentic teachers are listed as follows:

- Agentic teachers oppose the norms and regulations when they are not professionally appropriate, and perform appropriate practices by taking action in new ways (Toom, Pyhaltö \& Rust, 2015). 
- Agentic teachers do not have to oppose every change. If the changes are in place, they show moderate reactions (Tao \& Gao, 2017).

- Agentic teachers do not only perform the given complex tasks, but also have the desire and ability to develop their own competencies for lifelong learning and continuous professional development (Lipponen \& Kumpulainen, 2011).

- Agentic teachers make efforts to realize themselves (Ketelaar et al. 2012).

- Agentic teachers do not see teaching as just a profession; they evaluate teaching and what they do in this context as a meaningful job (Priestley, Biesta \& Robinson, 2015).

- Agentic teachers are committed to being a specific 'type' of teacher (teacher profile of their ideal) that has been in their mind (Tao \& Gao, 2017).

- Agentic teachers make active efforts to achieve various goals based on their beliefs about their professional roles (Biesta et al., 2015).

- Agentic teachers can get out of the teaching roles expected from them and they can resist when there is a mismatch between their beliefs and the policies they are expected to follow (Buchanan, 2015).

- Agentic teachers see schools as potential areas for ensuring and promoting social equality (Villegas \& Lucas, 2002).

- Agentic teachers make their decisions at work based on their own choices, purposes and interests (Vahasantanen, 2008).

- Agentic teachers have a growth mindset. These teachers think that learning and development is the path to success and they learn from the success of others (Allen, 2018).

- Agentic teachers have skills such as seeing possibilities, willingness to act, taking initiative, self-reflection, self-regulation, perseverance and self-efficacy and they carry moral responsibility (Paris \& Lung, 2008).

- Agentic teachers are more aware of their professional development than passively responding to learning opportunities and make learning choices to achieve their goals (Calvert, 2016).

- Agentic teachers plan and carry out professional learning practices. They participate in professional development activities for purposes such as improving teaching skills, collaborating with colleagues, selfactualization, and preparing students for the future. They are aware that the source is actually themselves in solving problems. They decide what to learn in in-service training activities (Calvert, 2016).

\section{Study Areas of Teacher Agency}

Teacher agency has been studied in many areas such as social justice (Pantic, 2017), positioning theory (KayiAydar, 2015), methodological approach and agency relationship in teaching English (Anwuruddin, 2017), professional vocational rights of teachers (Oolbekkink-Marchand et al., 2017), teacher beliefs ( Biesta et al., 2015), child-oriented practices (Paris \& Lung, 2008), bilingual education (Ray, 2009) and formative teacher evaluation (Verberg, Tigelaar, van Veen \& Verloop, 2016). On the other hand, the literature considers teacher agency as a concept related to teacher identity and an element of teacher identity. However, when studies are examined, the effect, role and development process of teacher agency in two areas come to the fore. These are educational changes in curricula, educational policies, or other areas related to education, mostly involving reforms or changes from the center, and professional development elements that involve teachers' continuous learning and self-development throughout their careers. These two areas are examined below, respectively.

\section{Educational changes}

Research in recent years characterizes teacher agency through teachers' reactions to changes in education (Pantic, 2017; Tao \& Gao, 2017). Teacher agency occurs when teachers try to control or influence / change their curricula to achieve their desired goals (Jenkins, 2019). The effects of postmodern or neo-liberal approaches on teacher education and education in general have a role in this case. Teacher agency has been an important concept in the literature on educational changes because it affects the implementation of educational policies at the institutional and national level. In the studies carried out, it is put forth that teachers are not technicians who apply policy changes; on the contrary, they respond to these changes at different levels and exert a variety of responses such as opposition, indecision or approval (Tao \& Gao, 2017). Teachers are agents acting passively or actively, not pawns assigned to a task during the reform process (Lasky, 2005). The factors that determine whether education change or reform attempts are successful are the teachers who teach in the classes (Fu \& Clarke, 2017). 
Jenkins (2019) analyzed the processes during a curriculum change in a school in Australia, focusing on teacher agency as part of a longitudinal study. As a result of the study, it was seen that teacher agency was practiced in three different ways: a) the proactive agency in which teachers apply curriculum change as a personal choice, b) the reactive agency in which teachers are forced to change as a result of extrinsic effects such as directives from the administration and c) the passive agency in which teachers seem to have applied changes to the administration, but in fact, they are passive agents that resist program change at a passive level. Alvunger (2018), on the other hand, expresses the role of the teacher during the enactment of the official curriculum in the classroom as curriculum agency. Curriculum agency, which is attributed to Doyle's (1992) view that teachers actually author curriculum activities/practices in the process of enactment of written curriculum text in the classroom, involves re-contextualization of curriculum in the classroom and is composed of three spaces. Accordingly, the first space is the common space where the tasks in curricula are transformed into pedagogical plans. The second space that follows is the individual space that includes the use of these pedagogical plans and the selection of teaching materials in the creation of lesson plans. In the third space, which is expressed as an interactive space between teachers and students, there are questions regarding choices made during the application, experience-based content and the process (Alvunger, 2018).

The view that includes the development of curricula by specialists other than teachers and the teachers' faithful implementation of these curricula is considered as one of the biggest obstacles to teacher agency (Sannino, 2010). Teacher proof curriculum approaches or such perspectives on teaching profession limit teacher agency. Besides, accountability-based curriculum approaches also limit teachers' ability to act individually or with colleagues (Sloan, 2006). Accountability pressures change teaching culture and teacher agency, and force teachers to focus on increasing students' success in standardized tests (Mifsud, 2018). It can be stated that the bottom-up approach in the curriculum development literature is more suitable for agency. In this approach, proposed by Taba (1962), teachers take the initiative and create elements of the curriculum such as purpose and content themselves. In fact, with this approach, the gap between curriculum and teaching disappears, and theory and practice are integrated (Henson, 1995). Similarly, this curriculum approach gives teachers a space of agency. In countries such as Turkey, where curricula are developed by central administration units, at least views of teachers can be resorted to, and maneuver spaces can be provided for teachers in the implementation of curricula. However, both the accountability approach that is becoming widespread and the pressure of the central exams do not make this much possible.

In line with the bottom-up approach, in developmentally appropriate and culturally sensitive approaches, teachers are the designers of the curricula rather than being the practitioners of a generic curriculum prepared by someone outside the classroom, and the needs, interests, experiences and values of a certain group of students or families can be reflected in the program this way (Paris \& Lung, 2008). There are also teachers, though in minority, who can reflect this approach to the classroom despite the curricula designed from the center. This is only possible with teacher agency. The fact that there are such teachers shows that contextual conditions can affect the agency but cannot completely hinder it.

In the process of program reforms or changes, an effective and appropriate school leadership or administration is needed for an effective proactive and reactive agency to occur. Passive agency occurs as a result of curriculum changes that are not implemented properly. Curriculum designers and decision makers should make sure that teachers understand the proposed changes, and they should do capacity building activities for teachers to plan and implement curriculum changes. There should be an open communication channel for all stakeholders to be informed and understand about the objectives and expected outcomes of the curriculum change (Jenkins, 2019). This is important for curriculum changes to be reflected in the class. When teachers show proactive activity, they own the program. Therefore, efforts should be exerted for teachers to develop feelings of belonging. On the other hand, it has been observed that teachers' vulnerabilities increase when the agency of teachers is limited especially in reform processes (Lasky, 2005).

It would be insufficient to address teacher agency only in the context of responding positively or negatively to the reforms of curriculum, policy or implementation coming from the center. In the literature, there is an approach that sees teachers as individuals who undertake change as well as seeing agency as a passive or active response to changes. According to Fullan (1993), teachers actually prefer this profession for responsibility or moral reasons, and supporting teachers to be actors of change allows them to develop strategies to achieve these ideals. When considered in the context of Turkey, it can be suggested that particularly in the early years of the Republic, teachers were agents of change aimed at improving the community and they worked tirelessly in very challenging conditions for this purpose. However, it does not seem possible to state that teacher education programs instill such an ideal in prospective teachers today. On the other hand, according to Fu and Ckarke (2017), it is stated that teacher candidates in Canada are supported to be the actors of change by 
trying to improve their inner worlds through strategies such as thoughtfulness, reflective practices, questioning and self-study. For pre-service teacher education, it is suggested to use autobiographical approaches that would ensure prospective teachers to question their own value systems and moral judges and thereby get engaged with inequities in social structures, and teacher educators should help prospective teachers to realize that history is not established by only heroes but also by mutual efforts of all members of the society and the present social structure is based on these efforts (Fu \& Clarke, 2017). In this way, teachers will realize that every attempt they make in the context of these ideals has a total meaning and will continue their profession in a meaningful way.

\section{Teacher agency in the context of professional development}

Teacher agency is not only important for teachers to go beyond the norms in order to realize the learning of students, but also for the continuous professional development of teachers, but it is clear that more research is needed in this regard (Toom, Pyhaltö \& Rust, 2015; Vahasanatenen, 2015). In the context of professional development, teacher agency is a holistic concept that includes the skills and abilities of the teacher to manage and promote learning in multiple professional contexts, especially in classrooms and within the professional communities (Toom, Pietarinen, Soini, \& Pyhaltö, 2017). Calvert (2016) defines teacher agency as the purposeful and constructive capacity to act in order to guide teachers' own professional development and contribute to their colleagues.

Agency should guide the individual's formation and reshaping of their professional knowledge, skills, identity, and transform their work-related actions (Lai, Li \& Gong, 2016). Agency is extremely important for participation in school cultures, where teachers are encouraged to take initiatives in pursuing professional development and developing collaboration between colleagues (Allen, 2018). It has also been revealed in studies that teacher agency plays an important role in teachers' professional development and continuous learning practices (Hökka, Etalaepelto \& Rasku-Puttonen, 2012; Lai, Li, \& Gong, 2016). Teacher agency involves learning motivation, self -efficacy beliefs regarding learning, purposeful activities and behaviors to manage new learning experiences as well as active and deliberate effort to promote learning in the professional community of individuals such as teachers, special education teachers, assistant staff, school psychologists, nurses and other social workers (Toom, Pietarinen, Soini, \& Pyhaltö, 2017). Teacher agency, which enables teachers to be aware of themselves and to evaluate themselves better in these purposeful activities and behaviors (Tao \& Gao, 2017), also plays an important role in maintaining their professional development. In cases where teacher agency and teacher learning are prioritized, professional learning communities that teachers will create may make a difference in school reform studies (Riveros, Newton \& Burgess, 2012). This situation reveals the capacity of the teacher agency, which has an individual aspect, to affect the school and the society positively as a result of the cooperation with all stakeholders. According to Calvert (2016), numerous activities are carried out on the professional development of teachers and large sums of money are spent on this subject, but the desired effect cannot be achieved. Teachers describe professional development activities or in-service training activities as "ineffective", "irrelevant" and "not helping students to improve their learning". Research studies on this subject revealed that teacher agency should be taken into consideration in terms of professional development activities that will contribute to teachers' learning. In the context of teachers 'professional development, teacher agency is an important factor in administrators' learning-centered leadership practices (Hallinger, Liu \& Piyaman, 2017). On the other hand, school administrators are known to have important effects on enabling teacher agency (Toom, Pyhaltö \& Rust, 2015). Calvert (2016) suggested what administrators should do in order to enable teacher agency in their professional learning / development processes:

Step 1: Make all professional learning decisions by having serious interviews with teachers and school heads. There should be at least $50 \%$ teacher representation in all stages of professional development activity such as planning, data analysis, design, implementation and evaluation.

Step 2: Review the arrangement of school hours. In this way, you get the opportunity for teachers to come together on a regular basis to collaborate with colleagues to improve the teaching and learning process.

Step 3: Include teachers and get their support in the process of analyzing the data and identifying teachinglearning difficulties.

Step 4: Build learning communities where teachers share responsibilities and solve problems in practice for the success of colleagues and students.

Step 5: Give teachers chance of choice related to professional learning, such as who to work with or what area to focus on.

Step 6: Make sure that the aim of professional learning is continuous improvement, not evaluation. 
Step 7: Do not enforce or highlight a particular professional learning activity without examining the context in which it will be applied. Learners (teachers) should want to develop their own practices and see how learning opportunities (professional development activity) can contribute to this.

\section{Studies on Teacher Agency in Turkey}

The concept of teacher agency on which a great deal of research in recent years on the international field has been conducted, is not yet adequately investigated in Turkey. The publications on teacher agency in Turkey accessed as a result of the literature review conducted are explained below in chronological order.

Yaylı (2017) used the concept of teacher agency as "öğretmen etkinliğgi" and approached the subject in the context of strategies to deal with tensions in the process of gaining teacher agency of prospective teachers. It was investigated how teacher candidates resolved the tensions they experienced during the school observation process and how they developed an agency in this direction.

Mutlu (2017) tried to determine the factors that affect teacher agency positively or negatively in relation to the professional space perceived by English teachers. Within the scope of this research which is based on the study by Ooolbekkink-Marchand et al. (2017), examining the changes in the career process, it was stated that the teachers have three basic trajectories in their professional career processes which are "contested agency, gradual growth of agency and failure in achievement of agency".

Within the scope of another research conducted by Erdem and Eğmir (2018), the concept of teacher agency was explained and international literature was presented. In addition, it was discussed whether teacher agency could take place in the Turkish education system.

Bellibaş, Çalışkan and Gümüş (2019), used “öğretmen failliği” for teacher agency and adapted a teacher agency scale developed by Liu, Hallinger and Feng in 2016. As a result of the study, it was revealed that the 24-item scale form collected under the dimensions of learning effectiveness, teaching effectiveness, optimism and constructive participation is a valid and reliable measurement tool. It is thought that the studies on the subject will increase with the introduction of this scale into Turkish.

Ataş Akdemir and Akdemir (2019) used “öğretmen aktörlüğü” for teacher agency and provided information about the concept of teacher agency, and they discussed the relationship between teacher agency and professional development, curricula and teacher identity. Based on this, they offered various suggestions regarding teacher agency.

\section{Conclusion}

Teachers face a wide variety of situations every day. These situations can sometimes contradict the teacher's value judgments, and the expectations from the central administration may come up against the autonomy of the teacher. The teacher needs to take various decisions in this process and take action on an active or passive level. Due to reasons such as the increasing complexity of the school's social ecosystem, increasing expectations from the center, the presence of pressure groups, teacher agency has become an important concept. In this context, this study attempts to fill the gap in the Turkish literature on issues such as the meaning, structure, and study areas of the concept of teacher agency, which has been emphasized in the international literature for a while. Three aspects should be taken into account in order for teachers to gain teacher agency, whose structure is explained above. These are laying the foundation of teacher agency in pre-service teacher education, arranging the context teachers work in line with teacher agency, and enhancement of teacher agency in in-service stage in the context of professional development.

Priestley et al. (2015) pointed out an issue in their explanation on why teacher agency should be understood. Accordingly, if agency is understood not as a capacity but as something acquired in the process, it will be easier for decision makers to understand the importance of the context. Teacher agency is affected by individual and socio-cultural factors including school structure and culture, power relationships, personal interests, identity, beliefs, context, past lives and expectations from the future (Lai, Li, \& Gong, 2016). In parallel, the structural factors encountered at the micro, middle and macro levels of the education system affect teachers' professional work and shape their agency (Toom, Pyhaltö \& Rust, 2015). In some cases, it can be seen that teachers who could actually be agentic are negatively affected by the context in which they are located. 
When this situation is understood, decision makers will not be attached to developing teacher capacity, they will also consider the context (Priestley et al., 2015).

If it is understood that agency is affected by past experiences, it will also be comprehended that today's contexts will determine the future agency levels of teachers. Thus, decision makers can also pay attention to cultural and structural areas that affect teachers' work as well as improving the capacity of the teacher (Priestley et al., 2015). However, it should not be understood from here that the arrangement of the context in which the teachers are working should be the only goal. Philpott (2017) also points to the need to focus on how and how much teachers can move around existing resources and contexts in addition to optimizing the context. For this reason, ministries of education should not exclude teachers from reform initiatives; on the contrary, they should consider them as agent stakeholders and enable them to embrace change. If the teachers do not adopt the change, it is not possible to transfer the change to the class.

In addition to understanding the importance of teacher agency, how to develop the agency is also significant. Teacher agency is accepted as a basic competence not only for students to learn but also for continuous professional development, collaborative teacher learning and school development; however, there is not enough understanding about the structure of teacher agency, the effect of pre-service teacher education on teacher agency and how educational policies affect and shape the agency at different stages of teaching career (Toom, Pyhaltö \& Rust, 2015). Within the scope of professional learning, it is important to design in-service trainings based on teacher agency. Teachers should decide for themselves what to learn, how to learn and how they can transfer what they have learned to the class based on the context they work. In this process, it is considered important that the teacher is equipped and the ministry provides the necessary coordination. On the other hand, relations among colleagues and school culture are also extremely important. Philpott (2017) proposes creating professional learning communities for this purpose.

Pre-service teacher education is also of great importance for teacher agency. As emphasized in teacher identity research, these efforts should be started in pre-service teacher education. It is extremely important that teacher candidates are trained as an agentic teacher, and this should be taken care of from the very beginning of pre-service teacher education (Soini et al., 2015) because what they learn in this process and their experiences affect their teacher identities (Ahonen et al., 2015). In the related studies, it has been put forth that some factors are effective in enhancing teacher agency which include experiences of trust and support among pre-service teachers' peers and faculty members, pre-service teachers' opportunities to opt for something, make an influence or participate actively to processes during pre-service teacher education, creation of learning environments in cooperation with pre-service teachers and faculty members, and faculty members' sharing authority with pre-service teachers (Juutilainen, Metsäpelto \& Poikkeus, 2018).

In pre-service teacher education, faculty members in education faculties should develop teacher agency in order to prepare teacher candidates for school culture, paying particular attention to teacher identity development. Since teacher agency requires a growth mindset, faculty members in education faculties should model this for pre-service teachers in their classes and teaching practices (Allen, 2018). Both pre-service teacher education and in-service teacher education should focus on reflective interaction and resource development such as knowledge, skill, belief, and value, and in professional development programs, the traditional ways of thinking about school imposed by society should be questioned and reflective thinking should be promoted (Priestley et al. 2015).

Although the importance of the concept of teacher agency has been emphasized in the literature, empirical studies on the development of the agency in teachers are insufficient (Oolbekkink-Marchand et al., 2017). It is observed that studies dwelling on this concept are quite limited in Turkey. The discussions on the quality of education in Turkey merely focus on educational system, methods of transitions among school levels and educational materials. However, it should not be forgotten that the most important factor of the quality of education is teachers. The most important factor affecting teachers' actions is their identity. For this reason, focusing on teacher identity and teacher agency as a part of it can be a guide in solving problems. 


\section{Öğretmen Kimliği Araştırmalarında Yeni Bir Kavram: Öğretmen Etkenliği \\ Cahit $\operatorname{Erdem}^{1 \dagger}$ \\ ${ }^{1}$ Afyon Kocatepe Üniversitesi}

\section{$\ddot{\mathbf{O} z}$}

Öğretmen kimliğinin bir ögesi olarak değerlendirilen öğretmen etkenliği son y1llarda üzerinde durulan bir kavram olarak karşımıza çıkmaktadır. Bununla birlikte, Türkiye'de bu kavram üzerine yapılmış akademik araştırmalar son derece sınırlıdır. Öyle ki kavramın Türkçesi konusunda dahi henüz bir fikir birliği bulunmamaktadır. Kavramın isimlendirilmesinde öğretmen etkenliği ifadesinin tercih edildiği bu çalışma kapsamında, kavramın Türkçe'deki karşılı̆̆ı, öğretmen kimliği ile ilişkisi, kavramın ortaya çıkışı ve tanımlanması, kuramsal alt yapısı, etken öğretmenlerin özellikleri, eğitimsel değişiklikler ve mesleki gelişim gibi ilgili çalışma alanları ve Türkiye'de bu konuda yapılan araştırmalar kapsamlı bir alan yazın incelemesine dayalı olarak açıklanmıştır. Ayrıca çalışmanın sonuç bölümünde, öğretmenlerin çalıştıkları bağlamların düzenlenmesi, hizmet içi eğitim ve hizmet öncesi öğretmen eğitimi kapsamlarında etkenliğin nasıl geliştirilebileceği de tartışılmıştır. Bu çalışma ile öğretmen etkenliği hakkında kapsamlı bir kaynak oluşturarak Türkiye'de yapılacak çalışmalara katkı sunmak hedeflenmektedir.

Anahtar Kelimeler: Öğretmen Failliği, Öğretmen Etkinliği, Eğitim Programı, Mesleki Gelișim, Etken Öğretmen

\section{Giriş}

Eğitim araştırmaları yerel ve küresel eğitim sorunlarına cevap bulabilmek için gerçekleştirilmekte ve araştırmaların eğilimleri zaman içerisinde farklı yöntem ve konulara yönelebilmektedir. Yeni kavramların ortaya çıkması, bazı kavramların öneminin anlaşııması, farklı ihtiyaçların gündeme gelmesi ya da bilimsel eğilimler gibi nedenlerle bazı alanlarda araştırmalar yoğunlaşmaktadır. Öğretmen kimliği çalışmaları da son yıllarda bu tür konulardan biri olmuştur. Uluslararası alan yazın incelendiğinde, öğretmen kimliği çalışmalarının özellikle 1990'lı yıllardan itibaren hız kazandığı görülmektedir (Beauchamp ve Thomas, 2009; Beijaard, Meijer ve Verloop, 2004). Öğretmenlerin kendilerini bir öğretmen olarak kendilerine ve diğer insanlara nasıl tanımladıkları şeklinde ifade edilen öğretmen kimliği (Lasky, 2005) benlik, yansıtma, duygular, geçmiş yaşantılar ve bağlamsal koşullar gibi birçok faktörden etkilenir (Beauchamp ve Thomas, 2009) ve öğretmenlerin kişisel benlik imajları ile sergilemekte oldukları sosyal roller arasında karmaşık ve dinamik bir denge kurma süreci olarak ifade edilebilir (Volkmann ve Anderson, 1998). Aslında öğretmen kimliği öğretmenlerin olmak istedikleri türden bir öğretmen olma kararlılıkları olarak da ifade edilebilir (Buchanan, 2015). Öğretmenlerin öğrenciler üzerindeki en önemli etken olmalar1 (Darling-Hammond, 1997), bir okulun niteliğinin öğretmeni geçemeyeceği (Kavcar, 1987) ve öğretmenliğin profesyonel yönü kadar sosyal yönünün de ön planda olduğu gibi gerçekler bir arada değerlendirildiğinde, öğretmen kimliği, üzerinde önemle durulması gereken bir nitelik olarak karşımıza çıkmaktadır.

Sosyal olduğu kadar öze dönük karmaşık bir yapıya sahip olması, hizmet öncesinden başlayarak öğretmenlik kariyerinin farklı basamaklarında önemli dönüşümler geçirmesi ve bağlamsal faktörlerden son derece etkilenmesi nedeniyle tanımlanması zor bir kavram olan öğretmen kimliği üzerine yapılan kapsamlı bir alan yazın incelemesinde, bu değişkenin dört boyutlu bir yapısının olduğu ileri sürülmüştür (Beijaard vd., 2004). Buna göre, öğretmen kimliği a) sürekli değişen ve dinamik bir yapıya sahiptir, b) bağlamsal faktörlerden etkilenir, c) alt-kimliklerden oluşmaktadır ve d) öğretmen etkenliği (teacher agency) kavramını içermektedir. Bu çalışmada Türkiye'de son birkaç yıla kadar dikkate alınmayan ancak öğretmen kimliği için son derece önemli olan, uluslararası alan yazında üzerinde yoğun bir şekilde durulan ve saygın akademik dergilerde hakkında özel sayılar çıkarılan öğretmen etkenliği kavramı üzerinde durulacaktır. Öğretmen etkenliği kimlik oluşumu ve gelişimi sürecinin temel ve ayrılmaz ögelerinden biridir (Allen, 2018; Parkison, 2008; Tao ve Gao, 2017). Bu kapsamda, kavramın ortaya çıkışı, tanımı ve kuramsal alt yapısı, etken öğretmenlerin özellikleri, ilgili çalışma alanları ve Türkiye'de bu konuda yapılan çalışmaların genel eğilimleri ortaya konulmaya çalışılacaktır. Bu

\footnotetext{
† Sorumlu Yazar: Cahit Erdem, cahiterdem@ gmail.com
} 
amaçla çalışma kapsamında ulusal ve uluslararası alan yazın ayrıntılı bir şekilde incelenmiş ve bu inceleme sonucunda kavram her yönüyle Türkçe alan yazına kazandırılmak istenmiştir. Bu yolla öğretmen etkenliği kavramına dikkat çekilerek kavram üzerine yapılacak çalışmalarda referans alınabilecek Türkçe bir kaynak oluşturmak amaçlanmıştır.

\section{Öğretmen Etkenliği}

\section{Kavramın Türkçesi}

İngilizce 'teacher agency' kavramının Türkçe karşılığ1 olarak öğretmen etkenliği ifadesinin uygun olduğu düşünülmektedir. 'Agency' terimi Merriam-Webster sözlüğünde bir eyleme geçmenin ya da güç kullanmanın kapasitesi, şartı ya da durumu olarak ifade edilmektedir. Yaylı (2017) bu kavram için 'öğretmen etkinliği’ kavramını, Bellibaş, Çalışkan ve Gümüş (2019) 'agency' kelimesinin Türkçe’ye faillik olarak çevrilmesinden hareketle 'öğretmen failliği’ kavramını ve Ataş Akdemir ve Akdemir (2019) 'öğretmen aktörlüğü’ kavramını kullanmışlardır. "Öğretmen Ağı” tarafından yayınlanan güncel bir raporda ise öğretmenin özne olma hali olarak ifade edilmiştir (Ayan, 2020). Türk Dil Kurumu (2019) tarafından etkin kavramı işleyen, çalışan olarak; fail kavramı bir işi yapan, eden işleyen olarak; aktör kavramı da bir olayda etkisi veya katkısı olan kimse olarak; özne kavramı da fail, bir işi yapan kişi olarak tanımlanmaktadır. Etken ise etki eden şey, faktör; bir madde üzerinde değişiklik yapan bir şey, müessir; edilgen karşıtı olarak tanımlanmaktadır. 'Teacher agency' kavramının kuramsal alt yapısı incelendiğinde, kavramın öğretmenlerin eyleme geçme kapasiteleri ile ilişkili olduğu, öğretmenliği teknisyenlikten çok inisiyatif alınan bir meslek olarak değerlendirdiği, özellikle öğretmenlerin merkezden gelen politikaları uygulama yaklaşımlarının önemli olduğu ve sosyal bağlamdan etkilendiği kadar sosyal bağlamı da önemli oranda etkilediği için öğretmen etkenliği kavramının daha kapsayıcı olacağ1 düşünülmüştür. Çünkü, 'teacher agency' kavramı öğretmenlerin içinde bulundukları bağlamda mevcut olan kural ve düzenlemelerin dışına çıkarak kendi amaçları doğrultusunda eyleme geçme yeterliklerini ifade eder (Oolbekkink-Marchand, Hadar, Smith ve Helleve, 2017). Bu nedenle, bu çalışmada 'teacher agency' kavramının karşılığı olarak ‘öğretmen etkenliği’ kullanılmıştır.

\section{Kavramın Ortaya Çıkışı ve Tanımı}

Öğretmen etkenliği üzerine önemli yayınlar yapan Priestley ve arkadaşları (2015) dünya genelinde uygulanan eğitim politikalarını, öğretmenlerin bu konulardaki rolünü ve öğretmenlerden beklenenleri değerlendirerek öğretmen etkenliğine neden ihtiyaç duyulduğunu açıklamışlardır. Buna göre, yüksek düzeyde yapılandırılmış eğitim programlarının oluşturulması, katı denetim ve eğitim programının içeriği ile öğretim yöntemlerinin merkezi yönetim tarafindan kontrol edilmesini içeren ve öğretmenlerin profesyonelleşmesine engel olan yaklaşımdan son yıllarda vazgeçilmeye başlanmıştır. Öğretmenden bağımsız bir eğitim programının uygulanması bir uygulama boşluğuna ve istenmeyen sonuçlara yol açmaktadır, çünkü öğretmenler genellikle durumu benimsemediklerinde hedeflerin aksine hareket edebilmektedirler (Priestley vd., 2015). Türk eğitim sistemi de uzun yıllardır bir değişim ve dönüşüm içindedir. Her ne kadar eğitim programları, öğretim kademeleri, kademeler arası geçiş sistemleri, öğretmen yetiştirme ve istihdam süreçleri, kullanılan öğretim materyalleri gibi birçok alanda sürekli bir reform çabası içinde olunsa da "Öğretmen Strateji Belgesi"nde de ifade edildiği üzere değişim çabalarının gerçekleşmesi öğretmenlere bağlıdır ve öğretmenler tarafindan benimsenmeyen değişimlerin sınıfa aktarılması imkânsızdır (Erdem ve Eğmir, 2018). Öğretmenler resmi öğretim programları ile uygulamadaki öğretim programları arasında bir köprü olarak değerlendirilebilir. Resmi programların ne oranda uygulamaya geçeceği öğretmenlere bağlıdır.

Uluslararası alanyazın ve uygulamalarda eğitim programı politikasının hayata geçirilmesinde öğretmenin rolü bağlamında üç temel eğitim politikası hayata geçmiştir (Priestley vd., 2015):

Bazı ülkelerde öğretmenler değișimin temel aktörleri olarak konumlandırılmaktadırlar ve program geliştirme çalışmalarında öğretmenler aktif görev almaktadırlar. İskoçya ve Güney Kıbrıs Rum Cumhuriyetinde son yıllarda gerçekleştirilen program reformları bu kapsamda değerlendirilebilir.

İkinci eğilim sürekli mesleki gelişim etkinlikleri aracılığıyla öğretmenlerin niteliğini geliştirmeye yönelik politikalardır. Mesleki öğrenme toplulukları, yeni öğretmen standartları ve öğretmenlerin lisansüstü düzeyde eğitim alması gereklilikleri bu kapsamda değerlendirilebilir.

Son yıllarda yükselen üçüncü eğilim ise ilk iki eğilim ile çelişmekte ve bu gelişmeleri olumsuz etkilemektedir. Üçüncü eğilim birçok ülkede hesap verilebilirlik sistemleri ve eğitimsel etkililiği ölçmek için ölçütler kullanılmasıdır. İlk iki eğilim, öğretmeni eğitim süreçlerinin merkezine yerleştirerek yıllardır devam eden kuralcı, merkezden yerele giden ve öğretmenleri dışlayan eğitim programı yaklaşımını ortadan kaldırmaya çalışırken son eğilim öğretmenin otonomisini ortadan kaldırmaya yöneliktir. 
İçeriklerin merkezden katı bir şekilde belirlenmesi yaklaşımı yerini okul denetimleri ve başarı verilerinin değerlendirilmesi yoluyla eğitim çıktılarının ön plana alınması düzenlemelerine bırakmaya başlamıştır (Kuiper vd., 2013). Bu son eğilim öğretmen otonomisine merkezi eğitim programı anlayışından daha fazla zarar vermiştir (Biesta, 2004; Priestley vd., 2015). Bu performansa dayalı yaklaşım okulda rekabet kültürü oluşturmakta, öğretmenleri dışarıya karşı iyi bir izlenim bırakmak için göstermelik bir performans göstermeye itmekte ve bu durum yolsuzluk, hile gibi etik dışı eylemlere bile neden olabilmektedir (Ball, 2003; Keddie vd. 2011; Priestley vd., 2015; Sahlberg, 2010). Söz konusu durum aynı zamanda öğretmenler üzerinde büyük baskılara neden olmakta, öğretmenlerin stres ve tükenmişlik düzeylerini olumsuz yönde etkileyebilmektedir. Türkiye'de uygulamaya konması düşünülen öğretmen performans sistemi bu üçüncü eğilimin bir parçası olarak görülebilir.

Öğretmenlerin eğitim politika ve reformlarının uygulamaya geçirilmesindeki hayati rolü, merkezi eğitim politikalarının zayıflayarak yerel koşulların daha çok dikkate alınmaya başlanması ve öğretmen kimliği üzerinde yapılan akademik araştırmalar öğretmen etkenliği kavramını ön plana çıkarmıştır. Öğretmenlerin öğretimsel koşulları sadece istek ve beceri gösterdiklerinde yani etken olduklarında olumlu yönde etkilediklerinin (Kayi-Aydar, 2015) anlaşılması bu durumda etkili olmuştur. Bu bağlamda öğretmen etkenliği öğretmenlerin nasıl eyleme geçeceklerinin ve politikalarla nasıl etkileşime geçeceklerinin anlaşılmasında işe koşulan bir kavram olarak ortaya çıkmıştır ancak kavramın tanımlanmasında önemli sorunlarla da karşılaşılmaktadır (Priestley vd., 2015).

İlk olarak, etkenlik kavramını tanımlamak faydalı olacaktır. Giddens'a (1984) göre etkenlik bireyin daha önceden var olan iş ya da eylemlerde değişiklik yapabilme yetisidir. Buna paralel olarak, etkenlik kişinin eylemlerinin ne düzeyde kendi kontrolünde olduğunu hissetme derecesi olarak tanımlanabilir (Beijaard, 2009). Roger ve Wetzel (2013) ise etkenliği bireylerin yaşamlarında amaçlı ve yansıtıcı bir şekilde eyleme geçme kapasitesi olarak görmektedir ancak Emirbayer ve Mische (1998) etkenliği bir kapasite olarak değil bağlamsal koşullar içerisinde edinilen bir şey olarak değerlendirmektedirler. Etkenlik bireyin geçmiş yaşantılarından, geleceğe dönük istek ve beklentilerinden ve içinde bulunduğu andaki bağlamla etkileşime geçerek gerçekleştirdikleri eylemlerden oluşur (Emirbayer ve Mische, 1998).

Öğretmen etkenliği kavramı psikolojide ele alınan etkenlik kavramının felsefi, psikolojik ve sosyal psikolojik temellerine dayanır (Paris ve Lung, 2008). Öğretmen etkenliği öğretmenlerin inançları, kişisel amaçlar, eğitim programı ve pedagoji bilgisi gibi etkenler tarafindan şekillendirilen dinamik bir süreçtir (Tao ve Gao, 2017). Etkenliği istek, otonomi, özgürlük ve seçim içeren amaçlı eylemlere girişme kapasitesi olarak tanımlayan Oolbekkink-Marchand (2017) öğretmenlik açısından ise etkenliği öğretmenlerin bağlamsal kural ve düzenlemelerin dışına çıkma ve kendi amaçlarına dayalı olarak eylemde bulunma becerisi olarak tanımlamaktadırlar. Etkenlik insanların sahip oldukları bir şey değil yaptıkları şeylerdir (Priestley vd. 2012), bir diğer ifade ile, eylem ön plandadır. Öğretmen etkenliği öğretmenlerin öğretmenlik sürecinde yaptıkları işleri ve içinde bulundukları durumu şekillendirmeye dönük aktif katkıları olarak tanımlanmaktadır (Biesta vd., 2015). Öğretmenler bu aktif katkılar yoluyla hem kendi öğrenmelerini artırmak hem de sınıflarında öğrencilerin en iyi şekilde öğrenmelerini mümkün kılmayı amaçlamaktadırlar (Pyhältö, vd., 2012).

Öğretmen etkenliği eğitsel değişikliklere tepki verme ya da mesleki gelişim gibi açılardan ele alınmıştır. Özellikle eğitim programı ya da politikalarında yapılan değişikliklere öğretmenlerin nasıl tepki verdikleri bu bağlamda incelenmektedir. Öğretmen etkenliği, öğretmenlerin kendilerinden uymaları beklenen norm ve düzenlemeler mesleki açıdan uygun olmadığında bu norm ve düzenlemeleri aşmak için yeni ve yaratıcı şekillerde eyleme geçmeyi ve hatta bunlara karşı durmayı içerir (Toom, Pyhaltö ve Rust, 2015). Etken bir öğretmenin içinde bulunduğu bağlamın özelliklerini ve kendi amaçlarını göz önünde bulundurarak farklı tepkiler vereceği beklenir. Öğretmen etkenliği eğitsel değişiklikler bağlamında tamamıyla uyum göstermekten direnç göstermeye ya da 1lımlı yaklaşmaya kadar farklı düzeylerde ortaya çıkabilir (Tao ve Gao, 2017). Bu durumun sebebi öğretmen etkenliğinin bireyden bireye de farklılık göstermesidir. Öğretmenlerin geçmiş yaşantıları ve çalışma bağlamları farklıdır (Kayi-Aydar, 2015).

Etkenlik öğretmenlerin mesleki öğrenmeleri için de önemlidir. Öğretmen etkenliği zorlu durumlarla başa çıkmaktan çok daha fazlasıdır. Etkenlik gelişim odaklı bir zihin yapısı gerektirir (Allen, 2018). Öğrencilerin hayatlarında olumlu değişiklikler yapmak için pedagojik yeterlik ve uzmanlığa da ihtiyaç bulunmaktadır (Anwaruddin, 2017). Mesleki gelişim bağlamında ise öğretmen etkenliği öğretmenlerin kendi mesleki gelişimlerini yönetme ve meslektaşlarını gelişimine de katkı sağlama becerisi ve inisiyatifi olarak tanımlanmaktadır (Allen, 2018). Etkenlik kişinin öğretmenlik kariyerine yön vermesi ve bu süreçte kendisine sadık kalması için bir araçtır (Ketelaar vd., 2012). Öğretmen etkenliği okulun, milli eğitimin ve daha geniş ulusal politikaların yapısal ve kültürel özellikleri ile iç içe geçen karmaşık bir dinamiğin bir parçasıdır (Mifsud, 
2018, s.194). Toplumun ve okulun yapısal ve kültürel özellikleri öğretmen etkenliğini etkiler ve öğretmen etkenliğinden etkilenir. Öğretmenin yaptığı her bir eylem ya da aldığı her bir karar geçmiş yaşantılardan, içinde bulunulan bağlamdan ve gelecekte yapılacak eylemleri etkileyecek şartlardan etkilenir (Lasky, 2005).

\section{Öğretmen Etkenliğinin Yapısı}

Öğretmenlerin politikaları uygulamaya geçirme sürecinde öğretmen etkenliği önemli bir kavram olarak karşımıza çıkmaktadır. Öğretmen etkenliğinin anlaşılması için yapılan çalışmalar içerisinde Priestley ve arkadaşlarının (2015) ortaya atmış oldukları ekolojik model alan yazında en çok kabul gören çerçeve olmuştur. Öğretmen etkenliğine yönelik ortaya konulan ekolojik model öğretmenin etkenlik kapasitesinin ve içinde bulunulan bağlamın koşullarının öğretmen etkenliğini şekillendirdiğini ileri sürmektedir. $\mathrm{Bu}$ modele göre etkenlik bireylerde yer alan bir kapasite ya da özellik değil gelişmekte olan bir olgudur (Priestley vd., 2015). Biesta ve Tedder'a (2007) göre etkenlik bireysel çabalar ile var olan kaynakların, bağlamsal ve yapısal faktörlerin ortak etkileşimi sonucunda ortaya çıkar. Bu nedenle etkenlik bireylerin sahip olduğu bir özellik değil elde edilen bir olgudur; bir diğer ifade ile, eylemde bulunanların bir niteliği değil eylemde bulunan kişilerin eylemi gerçekleştirdikleri bağlam ile etkileşimlerinin bir niteliğidir (Priestley vd., 2015). Ekolojik öğretmen etkenliği modeli Emirbayer ve Mische'nin (1998) psikolojide çalışılan etkenlik kavramı üzerindeki teorilerine dayanmaktadır. Etkenliğe ulaşmak üç temel boyut ile ilişkilidir. Etkenlik geçmişin etkileri, geleceğe yönelik yönelimler ve içinde bulunulan zaman ile bağlam arasındaki etkileşim sonucu ortaya çıkar (Priestley vd., 2015). Buna göre etkenlik zamansal etkenlere bağlıdır ve bağlamla yakın ilişki içerisindedir. Söz konusu bu üç boyutun yer aldığı ögretmen etkenliği ekolojik modeli Şekil 1'de verilmiştir.

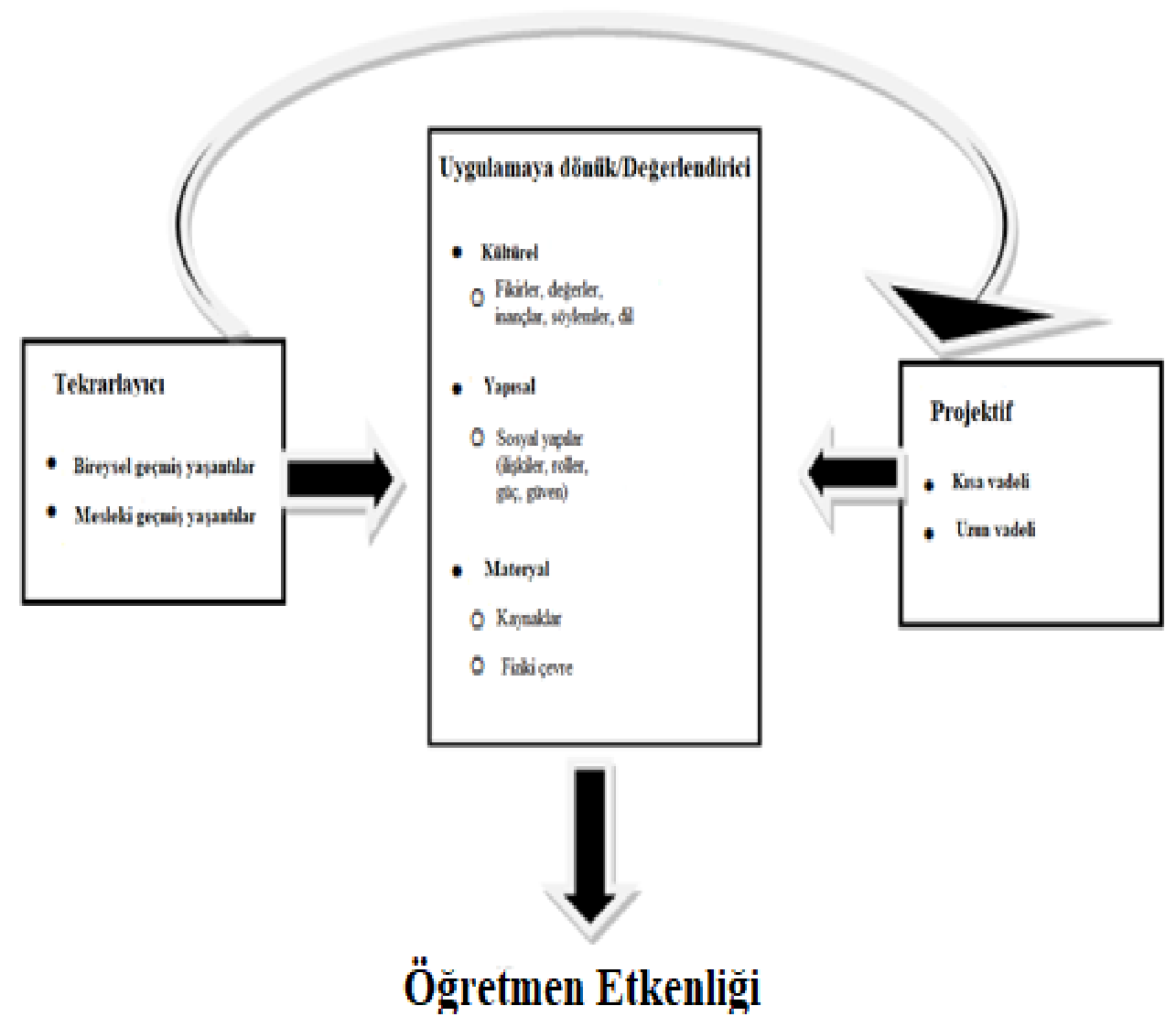

Şekil 1: Öğretmen Etkenliği Ekolojik Modeli (Priestley vd., 2015)

Modele göre öğretmen etkenliği tekrarlayıcı (iterational), uygulamaya dönük/değerlendirici (practicalevaluative) ve projektif boyutlarından oluşmakta ve etkilenmektedir. Bu modelin özellikleri aşağıda Priestley ve arkadaşlarının çalışmalarına (2015) dayalı olarak açıklanmıştır. 
Tekrarlayıcı boyut öğretmenin geçmiş yaşantıları ile ilgilidir. Tekrarlayıcı boyutta öğretmenlerin bireysel yaşam öyküleri ile mesleki geçmişleri arasında ayrım yapılmaktadır. Mesleki geçmiş hem öğretmenlerin bir öğretmen olarak kendi eğitimlerini hem de öğretmenlik tecrübelerini içermektedir. Burada dikkat edilmesi gereken husus ise modele göre öğretmenlerin geçmiş eylem ve düşünceler repertuarından seçim yapmasıdır. Alışkanlıklardan ziyade öğretmen mevcut sorunlarla başa çıkarken daha önceki deneyimlerinden ihtiyacına uygun olanları seçer ve bunu o anki pratiğinde işe koşar. Aynı zamanda bu deneyimler gelecekten beklentilerin oluşturulmasında da etkilidir. Bu durumda geçmiş deneyimleri daha zengin olan öğretmenlerin mevcut sorunlara daha çeşitli şekillerde tepki vermeleri ve geleceğe ilişkin daha geniş kapsamlı bir bakış açısı geliştirmeleri mümkündür. Bu bağlamda öğretmenlerin hem bireysel hem de mesleki geçmiş yaşantıları öğretmen etkenliği için önem taşımaktadır.

Projektif boyut gelecek ile ilgilidir. Bu boyut öğretmenlerin meslekleri bağlamında kısa ve uzun vadeli geleceğe dönük istek ve beklentilerini içermektedir. Öğretmenlerin oluşturdukları bu istek ve beklentiler tamamen olumlu olabilir ve öğretmenler öğrencilerin, okulun ve kendilerinin gelişimi için çaba gösterme eğiliminde olabilirler. Diğer yandan, bu istekler olumsuz olabilir ya da günü kurtarma veya olumsuzlukların üstünü örtme gibi araçsal istekler de olabilir. Geleceğe dönük bu beklenti ve istekler ne türden olursa olsun ve bunun arkasında yatan amaç ne olursa olsun, bu istekler öğretmenlerin değer ve inançlarına ve aynı zamanda geçmiş deneyimlerine dayanmaktadır.

Uygulamaya dönük/değerlendirici boyut içinde bulunulan zaman ile ilişskilidir. Etkenlik her ne kadar geçmiş ve gelecek ile ilişkili de olsa içinde bulunulan zamanda sergilenmektedir. Bu boyutta kültürel, yapısal ve materyal açılarından bir ayrım yapılmaktadır. Bu ögeler öğretmenlerin etkenliği edindiği şartları ve imkanları sağlayan mevcut bağlamı oluştururlar. Bu koşul ve imkanlar hem uygulamaya dönüktür (örneğin bağlamın kaynakları ve sınırlıkları düşünüldüğünde mümkün olanlar) hem de değerlendirici özelliğe sahiptir (risk değerlendirmelerine tabidir). Bu kapsamda, öğretmenlerin içinde bulundukları bağlamda karşı karşıya kaldıkları talepler, ikilemler ya da belirsizliklere tepki verirken çeşitli şekilde eyleme geçme seçenekleri mevcuttur. Bu seçenekler içerisinden, pratik ve normatif yargılara ulaşma ve eyleme geçme kapasitesi etkenliği belirler.

Bu modele göre etkenliğin elde edilmesi her zaman geçmiş yaşantılardan etkilenir. Kısa ve uzun vadeli amaç ve değerlerin bir ortak paydası içinde geleceğe dönük yönelimlerden etkilenir. Etkenlik her zaman somut bir ortamda gerçekleşir. Bu nedenle de eylemde bulunanların sahip olduğu kültürel, yapısal ve araçsal kaynaklar tarafindan sinırlandırılır ve desteklenir (Priestley vd., 2015).

Ekolojik yaklaşım öğretmen etkenliğinin öğretmenlerin içinde çalıştıkları bağlamdan ayrı düşünülemeyeceğini öngörmektedir (Biesta vd., 2015; Jenkins, 2019). Bu yaklaşımda öğretmenler bir çevrede eylemde bulunan aktörler değil o çevre aracılığı ile eyleme geçen kişilerdir ve öğretmenin eylemi aslında o çevreye verilen bir tepkidir (Biesta ve Tedder, 2006, Jenkins, 2019; Priestley, Biesta ve Robinson, 2016). Diğer yandan çevresel koşullar çeşitlidir. Karmaşık ve hızlı bir biçimde değişen okul çevresi, program değişikliklerine okul idaresinin yaklaşımı, özellikle müdürlerin rolü ve meslektaşlar arası ilişkiler bu kapsamda yer alır (Jenkins, 2019).

Jenkins (2019) öğretmen etkenliğinin karmaşık yapısının belirlenmesi, baştan itibaren izlenmesi ve öğretmen etkenliğini etkileyen bağlamsal faktörlerin ortaya konması amaciyla öğretmen etkenliği modelini ortaya atmıştır. Bandura'nın üçlü karşılıklı neden sonuç modeli ve etkenliğin temel kavramları modeline dayanan bu modeli Temel Etkenlik Kavramı Üçlü Karşılıklı Çerçevesi (Triadic Reciprocity Framework Core Agency Concepts- TRFCAC) olarak isimlendirmiştir. TRFCAC modeli Şekil 2'de sunulmuştur. 


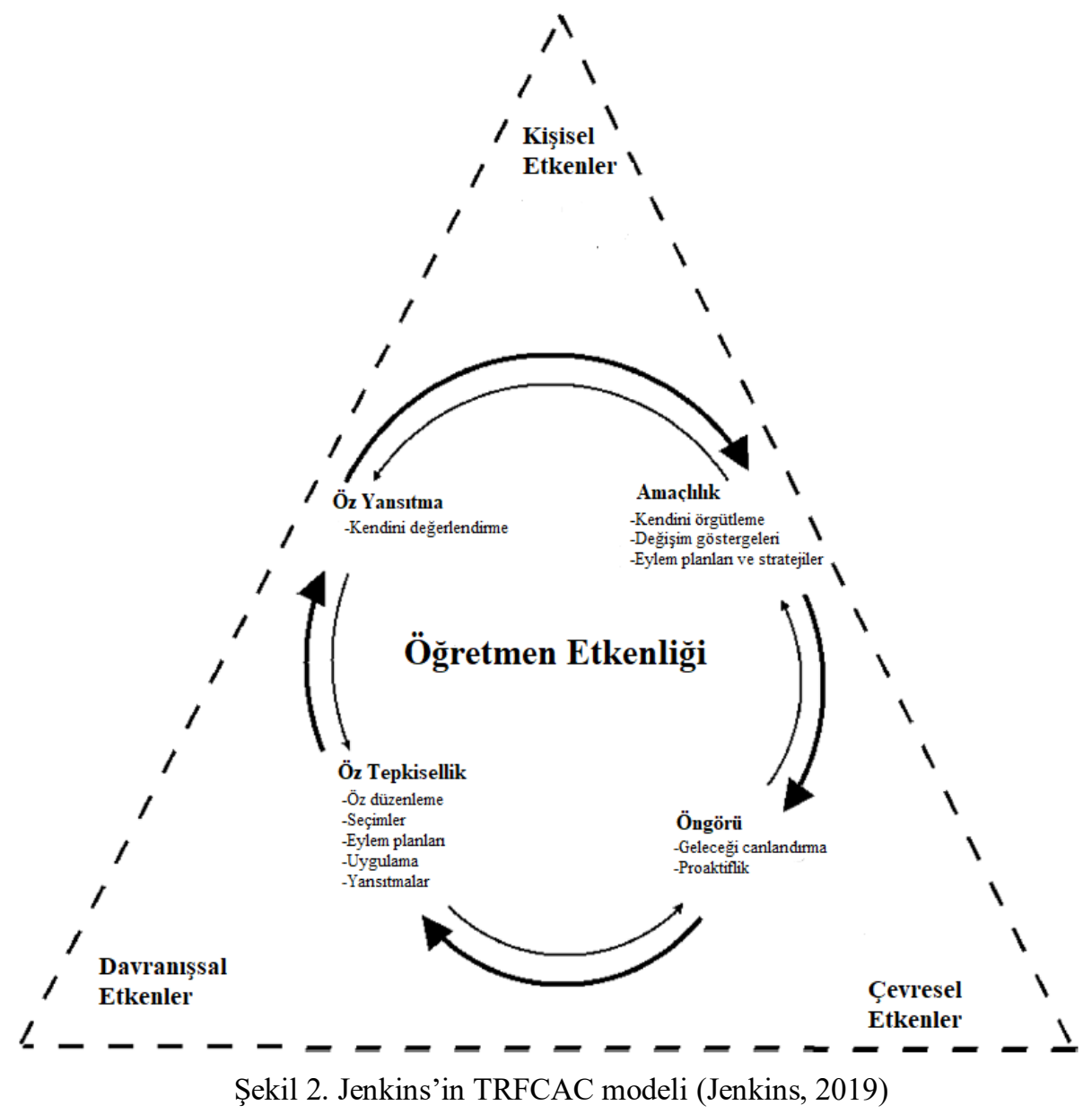

Bu model eğitim programı değişiklikleri ya da revizyonları sürecinde öğretmen etkenliğini anlamaya ilişkindir. $\mathrm{Bu}$ modele göre öğretmenler deneyimlerin üreticileridir ve olayları etkilerler. Gelecekteki olayların beklentilerine uygun olması ve istemedikleri eylemlerin de gerçekleşmemesi için etkileme imkânı olan şeyleri etkileme çabasında olurlar. Bu kapsamdaki eylemler de birbirleri ile ilişki içerisinde olan üç etmenden etkilenirler. Bu etkenler kişisel, çevresel ve davranışsal etkenlerdir. Bağlamsal faktörler arasındaki ilişkiler baskı ve etki bakımından sürekli değişirler. Başka bir ifade ile öğretmenler değişimin hem öznesi hem de faili olabilirler.

\section{Etken Öğretmenin Özellikleri}

Alan yazında öğretmen etkenliğinin tanımı ve yapısına yer verilirken etken (agentic) öğretmenin özellikleri de anlatılmıştır. Her şeyden önce etken öğretmenin kendi amaçları doğrultusunda inisiyatif alabilen öğretmenler olduğunu ifade etmek gerekmektedir. Bu inisiyatif bazen içinde bulunulan okulun ve eğitim sisteminin kurallarının dışına çıkmayı da gerektirebilir. Öğretmeni bu duruma iten öğretmenin öğrenmeye dönük inançları, geçmiş tecrübeleri, gelecekten beklentileri, ahlaki sorumluluk duygusu, öğrenci başarısının öncelenmesi gibi etmenler olabilir. Diğer yandan, etkenlik için en önemli boyut eyleme geçmedir. Öğretmen bu eylemler yoluyla çevresini şekillendirmeye çalışır ve sonuç olarak öğrencilerin eğitim ve öğretim hizmetinden en iyi şekilde yararlanması hedeflenir. Bu durumda etken öğretmenlerin özelliklerinin bir kısmı aşağıdaki gibi listelenmiştir:

- Etken öğretmenler norm ve düzenlemeler mesleki açıdan uygun olmadığında bunlara karşı çıkarlar ve yeni yollarla eyleme geçerek doğru uygulamalar yaparlar (Toom, Pyhaltö ve Rust, 2015).

- Etken öğretmen her değişikliğe karşı çıkmak durumunda değildir. Değişiklikler yerinde ise 1lımlı tepkiler gösterirler (Tao ve Gao, 2017).

- Etken öğretmenler sadece verilen karmaşık görevleri yerine getirmezler aynı zamanda yaşam boyu öğrenme ve sürekli mesleki gelişim için kendi yeterliklerini geliştirme istek ve becerisine sahiptirler (Lipponen ve Kumpulainen, 2011).

- Etken öğretmenler kendilerini gerçekleştirmek için çaba gösterirler (Ketelaar vd. 2012). 
- Etken öğretmenler öğretmenliği sadece bir meslek olarak görmezler; öğretmenliği ve bu kapsamda yaptıklarını anlamlı bir iş olarak değerlendirirler (Priestley, Biesta ve Robinson, 2015).

- Etken öğretmenler akıllarında yer etmiş olan belirli bir 'türdeki' öğretmen (ideallerindeki öğretmen profili) olmaya kendilerini adamışlardır (Tao ve Gao, 2017).

- Etken öğretmenler mesleki rolleri hakkındaki inançlarına dayalı olarak çeşitli amaçları gerçekleştirmek için aktif çaba gösterirler (Biesta vd., 2015).

- Etken öğretmenler kendilerinden beklenen öğretmenlik rollerinin dışına çıkabilirler ve kendi inançları ve uymaları beklenen politikalar arasında bir uyumsuzluk olduğunda karşı durabilirler (Buchanan, 2015).

- Etken öğretmenler okulları sosyal eşitliğin sağlanması ve teşvik edilmesi için potansiyel alanlar olarak görürler (Villegas ve Lucas, 2002).

- Etken öğretmenler işte aldıkları kararları kendi seçimleri ile ve kendi amaç ve ilgilerine dayalı olarak alırlar (Vahasantanen, 2008).

- Etken öğretmenler gelişim odaklı bir zihin yapısına (growth mindset) sahiptir. Bu öğretmenler öğrenme ve gelişmenin başarıya giden yol olduğunu düşünürler ve başkalarının başarılarından da öğrenirler (Allen, 2018).

- Etken öğretmenler olasılıkları görme, eyleme geçme istekliliği, inisiyatif alma, öz yansıtma, öz düzenleme, sebat, öz yeterlik gibi yetilere sahiptir ve ahlaki sorumluluk taşırlar (Paris ve Lung, 2008).

- Etken öğretmenler öğrenme firsatlarına pasif olarak tepki vermekten ziyade mesleki gelişimlerinin farkındadırlar ve amaçlarına ulaşmak için öğrenme seçimleri yaparlar (Calvert, 2016).

- Etken öğretmenler mesleki öğrenme süreçlerini planlarlar ve gerçekleştirirler. Öğretim becerilerini geliştirmek, meslektaşlarla iş birliği kurmak, kendini gerçekleştirmek ve öğrencileri geleceğe hazırlamak gibi amaçlarla mesleki gelişim etkinliklerine dâhil olurlar. Problemlerin çözümünde kaynağın aslında kendileri olduklarının farkındadırlar. Hizmet içi eğitim etkinliklerinde ne öğreneceklerine kendileri karar verirler (Calvert, 2016).

\section{Öğretmen Etkenliğinin Çalışma Alanları}

Öğretmen etkenliği sosyal adalet (Pantic, 2017), konumlandırma teorisi (Kayi-Aydar, 2015), İngilizce öğretiminde yöntemci yaklaşım ve etkenlik ilişkisi (Anwuruddin, 2017), öğretmenlerin mesleki söz hakları (Oolbekkink-Marchand vd., 2017), öğretmen inançları (Biesta vd., 2015), çocuk odaklı uygulamalar (Paris ve Lung, 2008), çift dilli eğitim (Ray, 2009), biçimlendirici öğretmen değerlendirme (Verberg, Tigelaar, van Veen ve Verloop, 2016) gibi çok farklı bağlamlarda çalışılmıştır. Diğer yandan, alan yazın öğretmen etkenliğini öğretmen kimliği ile ilişkili bir kavram ve öğretmen kimliğinin bir ögesi olarak değerlendirmektedir. Ancak çalışmalar incelendiğinde, öğretmen etkenliğinin temel olarak iki alandaki etkisi, rolü ve gelişim süreci ön plana çıkmaktadır. Bunlar eğitim programlarındaki, eğitim politikalarındaki ya da eğitimle ilgili diğer alanlardaki çoğunlukla merkezden gelen reformları ya da değişiklikleri içeren eğitimsel değiş̧iklikler ve öğretmenlerin kariyerleri boyunca sürekli öğrenme ve kendilerini geliştirmelerini içeren mesleki gelişim ögeleridir. Bu iki öge aşağıda sırasıyla incelenmiştir.

\section{Eğitimsel Değişiklikler}

Son yıllardaki araştırmalar öğretmen etkenliğini eğitim ile ilgili değişikliklere öğretmenlerin tepkileri üzerinden karakterize etmektedir (Pantic, 2017; Tao ve Gao, 2017). Öğretmen etkenliği öğretmenler istedikleri amaçlara ulaşmak için eğitim programlarını kontrol etmeye ya da etkilemeye/değiştirmeye çaba gösterdiklerinde ortaya çıkmaktadır (Jenkins, 2019). Post modern ya da neo-liberal yaklaşımların öğretmen eğitimine ve genel olarak eğitime etkileri bu durumda pay sahibidir. Öğretmen etkenliği eğitimsel değişimler üzerine gerçekleşen alan yazında önemli bir kavram olmuştur çünkü eğitim politikalarının kurumsal ve ulusal düzeyde uygulanmasını etkilemektedir. Yapılan çalışmalarda öğretmenlerin politika değişikliklerini uygulayan teknisyenler olmadıkları; aksine öğretmenlerin bu değiş̧ikliklere farklı düzeylerde ve karşı duruş, kararsızlık ya da onay gibi farklı çeşitlilikte tepkiler verdikleri ortaya koyulmuştur (Tao ve Gao, 2017). Öğretmenler reform sürecinde kendilerine görev verilen piyonlar değil pasif ya da aktif olarak eyleme geçen etkenlerdir (Lasky, 2005). Eğitimde değişim ya da reform girişimlerinin başarılı olup olmamasını belirleyen etmen sınıflardaki öğretimi gerçekleştiren öğretmenlerdir (Fu ve Clarke, 2017).

Jenkins (2019) Avustralya'da bir okulda eğitim programı değişikliği yaşanırken geçirilen süreçleri boylamsal bir çalışma kapsamında öğretmen etkenliğine odaklanarak incelemiştir. Çalışma sonucunda öğretmen etkenliğinin üç farklı şekilde sergilendiği görülmüştür: a) öğretmenlerin program değişikliğini kişisel bir seçim olarak uyguladıkları proaktif etkenlik, b) idareden gelen direktifler gibi çevresel etkilerin bir sonucu olarak 
öğretmenlerin değişim gerçekleştirmeye zorlandıkları tepkisel etkenlik ve c) öğretmenlerin idareye değişiklikleri uygulamış gibi göründükleri ama aslında program değişikliğine pasif düzeyde direndikleri pasif etkenlik. Alvunger (2018) ise yazılı olarak yer alan eğitim programlarının sınıfta uygulanması sürecinde öğretmenin rolünü eğitim programı etkenliği (curriculum agency) olarak ifade etmektedir. Doyle'nin (1992) eğitim programı metninin sınıfta gerçek öğretim içeriğine dönüşmesi sürecinde öğretmenin aslında eğitim programı etkinliklerinin/uygulamalarının yazarlığını yaptığı görüşüne dayandırılan eğitim programı etkenliği eğitim programının sınıfta yeniden bağlamsallaştırıldığını içermekte ve üç alandan oluşmaktadır. Buna göre birinci alan eğitim programlarında yer alan görevlerin pedagojik planlara dönüştürüldüğü müşterek alandır. Bunu takip eden ikinci alan ise ders planlarının oluşturulmasında bu pedagojik planların kullanılmasını ve öğretim materyallerinin seçimini içeren bireysel alandır. Öğretmen ve öğrenciler arasındaki etkileşimli alan olarak ifade edilen üçüncü alanda ise uygulama esnasında yapılan seçimler, deneyime dayalı içerik ve sürece ilişsin sorular bulunmaktadır (Alvunger, 2018).

Eğitim programlarının öğretmenler dışındaki uzmanlar tarafindan geliştirilmesi ve öğretmenlere sunularak öğretmenlerin sadık bir şekilde bu programları uygulamasını içeren bakış açısı öğretmen etkenliğinin önündeki en büyük engellerden birisi olarak görülmektedir (Sannino, 2010). Öğretmenden bağımsız eğitim programı yaklaşımları ya da öğretmenliğe yönelik bu tür bakış açıları etkenliği sınırlamaktadır. Diğer yandan, hesap verilebilirlik tabanlı eğitim programı yaklaşımları da öğretmenlerin bireysel ya da meslektaşları ile birlikte eyleme geçme yetilerini sınırlandırmaktadır (Sloan, 2006). Hesap verilebilirlik baskıları öğretim kültürünü ve öğretmen etkenliğini değiştirmektedir ve öğretmenleri öğrencilerin standart testlerdeki başarılarının artırmasına odaklanmaya itmektedir (Mifsud, 2018). Eğitim programı alan yazınında yer alan program geliştirmede aşağıdan yukarıya (bottom-up) yaklaşımın etkenlik için daha uygun olduğu ifade edilebilir. Taba (1962) tarafindan önerilen bu yaklaşımda öğretmenler inisiyatif alırlar ve programın amaç ve içerik gibi ögelerini bizzat kendileri oluştururlar. Aslında bu model ile eğitim programı ile öğretim arasındaki kopukluk ortadan kalkmakta ve teori ile pratik bütünleşmektedir (Henson, 1995). Benzer şekilde, bu eğitim programı yaklaşımı öğretmenlere etkenlik alanı tanımaktadır. Türkiye gibi merkezden eğitim programlarının belirlendiği ülkelerde en azından program geliştirme sürecinde öğretmenlerin görüşlerinden yararlanma yoluna gidilebilir ve eğitim programlarının uygulanması sürecinde öğretmene manevra alanları sunulabilir. Ancak gerek artık yaygınlaşmaya başlayan hesap verilebilirlik yaklaşımı gerek de merkezi sınavların baskısı bunu çok mümkün k1lmamaktadır.

Aşağıdan yukarıya yaklaşımla paralel olarak, gelişimsel olarak uygun ve kültürel özelliklere duyarlı yaklaşımlarda, öğretmenler sınıf dışından birisinin hazırladığı genel bir eğitim programının uygulayıcıları olmak yerine eğitim programlarının tasarımcısı konumundadırlar ve belirli bir grup öğrenci ya da ailelerin ihtiyaçları, ilgileri, deneyimleri ve değerleri programa yansitılabilmektedirler (Paris ve Lung, 2008). Her ne kadar bu tür yaklaşımlar azınlıkta da olsa merkezden uygulanan programlara rağmen bu yaklaşımı sınıfa yansıtabilen öğretmenler de bulunmaktadır. Bu da ancak öğretmen etkenliği ile mümkündür. Bu tür öğretmenlerin buluyor olması bağlamsal koşulların etkenliğe etki edebilmekle beraber etkenliği tamamen engelleyemediğini de göstermektedir.

Program reformları ya da değişiklikleri sürecinde ise etkili bir proaktif ve tepkisel etkenliğin ortaya çıkması için etkili ve uygun bir okul liderliğine ya da idaresine ihtiyaç vardır. Doğru şekilde uygulanmayan eğitim programı değişikliklerinin sonucunda pasif etkenlik ortaya çıkmaktadır. Program geliştirmeciler ve karar vericiler öğretmenlerin önerilen değişiklikleri anladıklarından emin olmalıdırlar ve öğretmenlerin program değişikliklerini planlama ve uygulamaları için kapasite geliştirme çalışmaları yapmalıdırlar. Program değişikliğinin amaçları ve beklenen çıtıları konusunda tüm paydaşların bilgilenmesi ve anlaması için açık bir iletişim kanalı olmalıdır (Jenkins, 2019). Bu durum program değişikliklerinin sınıfa yansıması için önem taşımaktadır. Öğretmenler proaktif etkenlik gösterdiklerinde programı sahiplenmektedirler. Bu nedenle, öğretmenlerin aidiyet duyguları geliştirmeleri için çalışmalar gerekmektedir. Diğer yandan, özellikle reform süreçlerinde öğretmenlerin etkenlikleri sınırlandırıldığında öğretmenlerin kırılganlıklarının arttığı görülmüştür (Lasky, 2005).

Öğretmen etkenliğini sadece merkezden gelen program, politika ya da uygulama reformlarına karşı pozitif ya da negatif yönde tepki verme bağlamında ele almak yetersiz kalacaktır. Alan yazında, etkenliği değişimlere pasif ya da aktif tepki vermek olarak görmenin yanı sıra öğretmenleri bizzat değişimi üstlenen bireyler olarak gören bir yaklaşım da mevcuttur. Fullan'a (1993) göre, öğretmenler aslında bu mesleği sorumluluk ya da ahlaki gerekçelerle tercih etmektedirler ve öğretmenleri değişimin aktörleri olması noktasında desteklemek onların bu ideallerini gerçekleştirmek için stratejiler geliştirmelerine imkân tanır. Türkiye bağlamında düşünüldüğünde, özellikle Cumhuriyet'in ilk yıllarında öğretmenlerin eğitim yoluyla toplumu geliştirmeyi amaçlayan değişim aktörleri olduğunu söylemek ve bu amaçla çok zorlu şartlarda yılmadan 
çalıştıkları ifade etmek yanlış olmayacaktır. Ancak günümüzde öğretmen eğitim programlarının öğretmen adaylarına böyle bir ideali aşıladığını ifade etmek çok mümkün görünmemektedir. Diğer yandan, Fu ve Ckarke'a (2017) göre Kanada'daki öğretmen eğitim programlarında, düşüncelilik, yansıtıcı uygulamalar, sorgulama ve öz çalışma gibi stratejilerle öğretmen adaylarının iç dünyalarının geliştirilmeye çalışılarak değişimin aktörleri olma yolunda onların desteklendiği ifade edilmektedir. Hizmet öncesi öğretmen eğitiminde ögretmen adaylarının kendi değer sistemlerini ve ahlaki yargılarını sorgulamalarına ve buna dayalı olarak sosyal yapıdaki eşitsizlikler ile ilgilenmelerini sağlayacak otobiyografik yaklaşımların kullanılması önerilmektedir ve öğretmen eğitimcileri öğretmen adaylarının tarihin sadece kahramanlar tarafından oluşturulmadığının tersine tüm insanların ortak çabaları sonucu oluştuğunun ve mevcut sosyal yapıların buna dayandığının farkına varmalarına yardımcı olmalıdır (Fu ve Clarke, 2017). Bu yolla öğretmen bu idealler kapsamında yaptığı her girişimin toplamda bir anlam taşıdığının farkına varacak ve yaptığı mesleği anlamlı bir biçimde sürdürecektir.

\section{Mesleki Gelişim Bağlamında Öğretmen Etkenliği}

Öğretmen etkenliği sadece öğrencilerin öğrenmesinin gerçekleşmesi amaciyla öğretmenlerin normların dışına çıkması noktasında değil öğretmenlerin sürekli mesleki gelişimleri için de önem taşımaktadır ancak bu konuda daha çok araştırmaya ihtiyaç duyulduğu açıktır (Toom, Pyhaltö ve Rust, 2015; Vahasanatenen, 2015). Mesleki gelişim bağlamında öğretmen etkenliği öğretmenin özellikle sınıflarda ve mesleki topluluk içerisinde olmak üzere çoklu mesleki bağlamlarda öğrenmeyi yönetme ve teşvik etme beceri ve yeteneklerinin yanı sıra bilişlerini, güdülerini ve tutumlarını içeren bütüncül bir kavramdır (Toom, Pietarinen, Soini ve Pyhaltö, 2017). Calvert (2016) öğretmen etkenliğini öğretmenlerin kendi mesleki gelişimlerini yönlendirmek ve meslektaşlarına katkıda bulunmak amacıyla amaçlı ve yapıcı bir biçimde eyleme geçme kapasitesi olarak tanımlamaktadır.

Etkenlik bireyin mesleki bilgisini, becerilerini, kimliklerini oluşturmasını ve yeniden şekillendirmesini yönlendirmelidir ve işle ilgili eylemlerini dönüştürmelidir (Lai, Li ve Gong, 2016). Öğretmenlerin, mesleki gelişimin takip edilmesi ve meslektaşlar arası iş birliğinin geliştirilmesinde inisiyatif almalarının teşvik edildiği okul kültürlerine katılım için etkenlik son derece önemlidir (Allen, 2018). Öğretmenlerin mesleki gelişimlerinde ve sürekli öğrenme süreçlerinde öğretmen etkenliğinin önemli bir rolü olduğu yapılan araştırmalarda da ortaya koyulmuştur (Hökka, Etalaepelto ve Rasku-Puttonen, 2012; Lai, Li ve Gong, 2016). Öğretmen etkenliği öğretmenler, özel eğitim öğretmenleri, yardımcı personeller, okul psikologları, hemşireleri ve diğer sosyal çalışanlar gibi bireylerin yer aldığı mesleki topluluk içerisinde öğrenmeyi teşvik etmek için gösterilen aktif ve kasıtlı çabanın yanı sıra öğrenme motivasyonunu, öğrenme açısından öz yeterlik inançlarını, yeni öğrenmeleri yönetmek için amaçlı etkinlikleri ve davranışları içerir (Toom, Pietarinen, Soini ve Pyhaltö, 2017). Bu amaçlı etkinlik ve davranışlar sürecinde öğretmenlerin kendilerinin farkında olmalarını ve kendilerini daha iyi değerlendirmelerini sağlayan öğretmen etkenliği (Tao ve Gao, 2017) öğretmenlerin mesleki gelişimlerini sürdürmelerinde de önemli bir rol oynar. Öğretmen etkenliğine ve öğrenmesine öncelik verilmesi durumunda öğretmenlerin oluşturacakları mesleki öğrenme toplulukları okul reformu çalışmalarında farklılık yaratabilir (Riveros, Newton ve Burgess, 2012). Bu durum ise bireysel bir yönü olan öğretmen etkenliğinin tüm paydaşlarla iş birliği sonucunda okulu ve dolayısıyla toplumu olumlu yönde etkileme kapasitesini ortaya koymaktadir.

Calvert'e (2016) göre öğretmenlerin mesleki gelişimi konusunda sayısız çalışmalar yapılmakta ve bu konuda büyük paralar harcanmaktadır ancak istenen etkiye ulaşllamamaktadır. Öğretmenler mesleki gelişim etkinliklerini ya da hizmet içi eğitim etkinliklerini "etkisiz", "illgisiz" ve "öğrencilerin öğrenmesini geliştirmelerine yardımcı olmayan” etkinlikler olarak nitelemektedirler. Bu konuda yapılan araştırmalar öğretmenlerin öğrenmesine katkı sunacak mesleki gelişim etkinlikleri konusunda öğretmen etkenliğinin dikkate alınması gerektiği sonucunu ortaya koymuştur. Öğretmenlerin mesleki gelişimleri bağlamında, öğretmen etkenliği yöneticilerin öğrenme merkezli liderlik uygulamalarında bulunmalarında önemli bir etkendir (Hallinger, Liu \& Piyaman, 2017). Diğer yandan, okul yöneticilerinin ise öğretmen etkenliğinin oluşumuna imkân tanımada önemli etkileri olduğu bilinmektedir (Toom, Pyhaltö ve Rust, 2015). Calvert (2016) eğitim yöneticilerinin mesleki öğrenme/gelişim süreçlerinde öğretmen etkenliğini artırabilmeleri için yapmaları gerekenleri şöyle önermiştir:

Adım 1: Bütün mesleki öğrenme kararlarını öğretmenler ve okul müdürleri ile ciddi görüşmeler yaparak alın. Mesleki gelişim etkinliğini planlama, veri analizi, tasarlama, uygulama ve değerlendirme gibi bütün aşamalarında en az \%50 öğretmen temsili olmalıdır.

Adım 2: Okul saatlerinin düzenlemesini gözden geçirin. Bu şekilde öğrenme öğretme sürecini geliştirmek için öğretmenlerin meslektaşları ile işbirliği yapmak için düzenli bir şekilde bir araya gelme firsatı olsun.

Adım 3: Verilerin analiz edilmesi ve öğretme öğrenme zorluklarının belirlenmesi süreçlerine öğretmenleri dâhil edin ve desteklerini alın. 
Adım 4: Öğretmenlerin meslektaşlarının ve öğrencilerin başarısı için sorumluluklarını paylaştıkları ve uygulamadaki sorunları çözdükleri öğrenme toplulukları oluşturun.

Adım 5: Öğretmenlere kimle çalışacakları, hangi alana odaklanacakları gibi mesleki öğrenmeye ilişkin konularda seçim şansı sunun.

Adım 6: Mesleki öğrenmenin amacının değerlendirme değil sürekli gelişim olduğundan emin olun.

Adım 7: Uygulanacağı bağlamı derinlemesine incelemeden belirli bir mesleki öğrenme etkinliğini zorunlu koşmayın ya da ön plana çıkarmayın. Öğrenenlerin (öğretmenlerin) kendi uygulamalarını geliştirmek istemeleri ve öğrenme firsatının (mesleki gelişim etkinliğinin) buna nasıl katkı yapacağını görmeleri gerekmektedir.

\section{Türkiye'de Öğretmen Etkenliği Üzerine Yapılan Çalışmalar}

Uluslararası alan yazında son yıllarda üzerinde çok çeşitli araştırmalar yapılan öğretmen etkenliği kavramının Türkiye'de henüz yeterli düzeyde araştırılmadığı görülmektedir. Yapılan alan yazın araştırması sonucunda öğretmen etkenliği üzerine gerçekleştirilen ve erişilebilen yayınlar aşağıda kronolojik sıra ile açıklanmıştır. Yaylı (2017) öğretmen etkenliğini öğretmen etkinliği olarak ifade etmiş ve konuya öğretmen adaylarının öğretmen etkenliğini kazanma sürecinde gerginliklerle başa çıkma stratejileri bağlamında yaklaşmıştır. Öğretmen adaylarının okul gözlemi sürecinde yaşadıkları gerginlikleri nasıl çözümledikleri ve bu yönde nasıl bir etkenlik geliştirdikleri incelenmiştir.

Mutlu (2017) görev yapmakta olan İngilizce öğretmenlerinin algıladıkları mesleki söz hakları (professional space) ile ilişkili olarak öğretmen etkenliğini olumlu ya da olumsuz yönde etkileyen faktörleri belirlemeye çalışmıştır. Ooolbekkink-Marchand ve arkadaşlarının (2017) yaptıkları ve kariyer sürecindeki değişimleri incelemeyi temele alan bu araştırma kapsamında öğretmenlerin mesleki kariyer süreçlerinde mücadeleci etkenlik, zaman içerisinde aşamalı etkenlik gelişimi ve etkenlik geliştirememe gibi üç temel eğilim içerisinde oldukları ifade edilmiştir.

Erdem ve Eğmir (2018) tarafindan yapılan bir başka araştırma kapsamında ise öğretmen etkenliği kavramı açıklanmış ve uluslararası alan yazında ne tür çalışmalar yapıldığına yer verilmiştir. Ayrıca Türk eğitim sistemi içerisinde öğretmen etkenliğinin yer alıp alamayacağı tartışılmıştır.

Bellibaş, Çalışkan ve Gümüş (2019) öğretmen etkenliğini öğretmen failliği olarak ifade etmiş ve bu kapsamda Türkiye'de bu kavramın ölçülmesine yönelik bir ölçme aracı bulunmadığından hareketle Liu, Hallinger ve Feng tarafından 2016 yılında geliştirilen öğretmen etkenliği ölçeğini Türkçeye uyarlamışlardır. Çalışma sonucunda öğrenme etkililiği, öğretme etkililiği, iyimserlik ve yapıcı katılım boyutları altında toplanan 24 maddelik ölçek formunun geçerli ve güvenilir bir ölçme aracı olduğu ortaya koyulmuştur. Bu ölçeğin Türkçeye kazandırılması ile konu hakkında yapılan çalışmaların artacağı düşünülmektedir.

Ataş Akdemir ve Akdemir (2019) öğretmen etkenliğini öğretmen aktörlüğü olarak ifade ettikleri kavramsal çalışmalarında öğretmen aktörlüğü kavramını hakkında bilgi vermişlerdir ve öğretmen aktörlüğünün öğretmenlerin mesleki gelişimi, eğitim programları ve öğretmen kimliği alanları ile ilişkisini ele almışlardır. Buna dayalı olarak da öğretmen aktörlüğüne ilişkin çeşitli öneriler getirmişlerdir.

\section{Sonuç}

Öğretmenler her gün çok çeşitli durumlar ile karşı karşıya kalmaktadırlar. Bu durumlar bazen öğretmenin değer yargıları ile çelişebilmekte, merkezden gelen beklentiler ile öğretmenin otonomisi karşı karşıya gelebilmektedir. Öğretmenin bu süreçte çeşitli kararlar alarak aktif ya da pasif düzeyde eyleme geçmesi gerekmektedir. Okulun sosyal ekosisteminin giderek karmaşıklaşması, merkezden gelen beklentilerin artması, baskı gruplarının varlığı gibi nedenlerle öğretmen etkenliği önemli bir kavram olarak karşımıza çıkmaktadır. Bu kapsamda bu çalışmada uluslararası alan yazında bir süredir üstünde önemle durulan öğretmen etkenliği kavramının anlamı, yapısı, çalışma alanları gibi konularda Türkçe alan yazındaki eksiklik doldurulmaya çalışılmıştır. Yapısı yukarıda açıklanmaya çalışılan öğretmen etkenliğinin öğretmenler tarafından edinilmesi için üç husus dikkate alınmalıdır. Bunlar hizmet öncesinde öğretmen etkenliğinin temelinin atılması, öğretmenlerin içindeki bulundukları bağlamın etkenliğe uygun hale getirilmesi ve hizmet içinde mesleki gelişim bağlamında öğretmen etkenliğinin geliştirilmesidir.

Priestley vd. (2015) öğretmen etkenliğinin neden anlaşılması gerektiğine dair yaptıkları açıklamada bir hususa dikkat çekmişlerdir. Buna göre, eğer etkenlik bir kapasite olarak değil de süreçte edinilen bir şey olarak anlaşılırsa, karar vericilerin bağlamın önemini anlamaları kolaylaşacaktır. Öğretmen etkenliği okul yapısından 
ve kültüründen, güç ilişkilerinden, kişisel ilgilerden, kimlikten, inançlardan, içinde bulunulan bağlamdan, geçmiş yaşantılardan ve gelecekten beklentilerden özetle bireysel ve sosyo-kültürel faktörlerden etkilenir (Lai, Li ve Gong, 2016). Buna paralel olarak, eğitim sisteminin mikro, orta ve makro düzeylerinde karşılaşılan yapısal faktörler öğretmenlerin mesleki çalışmalarını etkilemekte ve etkenliklerini şekillendirmektedir (Toom, Pyhaltö ve Rust, 2015). Bazı durumlarda etken olabilecek öğretmenlerin içindeki bulundukları bağlamdan olumsuz etkilendikleri görülmektedir. $\mathrm{Bu}$ durum anlaşıldığında karar vericiler öğretmen kapasitesini geliştirmeye takılı kalmayacak, bağlamı da göz önüne alacaklardır (Priestley vd., 2015).

Etkenliğin geçmiş yaşantılardan etkilendiğinin anlaşılması durumunda, günümüzdeki bağlamların öğretmenlerin gelecekteki etkenlik düzeylerini belirleyeceği de anlaşılmış olur. Böylelikle karar vericiler yine öğretmenin kapasitesini geliştirmek kadar öğretmenlerin işlerini etkileyen kültürel ve yapısal alanlara da dikkat edebilirler (Priestley vd., 2015). Ancak buradan öğretmenlerin içindeki bulundukları bağlamın düzenlenmesinin tek amaç olması gerektiği anlaşılmamalıdır. Philpott (2017) bağlamın uygun hale getirilmesinin yanı sıra öğretmenlerin var olan kaynak ve bağlamlar çerçevesinde nasıl ve ne kadar hareket edebileceklerine odaklanılması gerektiğine de işaret etmektedir. $\mathrm{Bu}$ nedenle, eğitim bakanlıkları öğretmenleri reform girişimlerinin dışında tutmamalı, aksine onları etken birer paydaş olarak değerlendirerek onların değişimi sahiplenmelerini sağlamalıdır. Çünkü öğretmenler değişimi benimsemez ya da sahiplenmez ise değişimin sınıfa aktarılması mümkün değildir.

Öğretmen etkenliğinin önemimin anlaşılmasının yanı sıra bu kapasitenin nasıl geliştirileceği de önem taşımaktadır. Öğretmen etkenliği sadece öğrencilerin öğrenmeleri için değil aynı zamanda sürekli mesleki gelişim, iş birlikli öğretmen öğrenmesi ve okul gelişimi için temel bir yeterlilik olarak kabul edilmektedir, ancak öğretmenlik kariyerinin farklı aşamalarında öğretmen etkenliğinin yapısı, hizmet öncesi öğretmen eğitiminin öğretmen etkenliği üzerindeki etkisi, eğitim politikalarının etkenliği ne düzeyde etkilediği ve şekillendirdiği gibi konularda yeterli düzeyde bilgi bulunmamaktadır (Toom, Pyhaltö ve Rust, 2015). Mesleki öğrenme kapsamında hizmet içi eğitimlerin öğretmen etkenliğine dayalı olarak oluşturulması önem taşımaktadır. Öğretmenler içinde bulundukları bağlam kapsamında ne öğreneceklerine, nasıl öğreneceklerine ve öğrendiklerini sınıfa nasıl aktaracaklarına kendileri karar vermelidirler. Bu süreçte öğretmenin donanımlı olması ve bakanlığın da gerekli koordinasyonu sağlaması önemli görülmektedir. Diğer yandan, meslektaşlar arası ilişkiler ve okul kültürü de son derece önemlidir. Philpott (2017) bu amaçla mesleki öğrenme toplulukları oluşturulmasını önermektedir.

Hizmet öncesi öğretmen eğitimi de öğretmen etkenliği için büyük önem taşımaktadır. Öğretmen kimliği araştırmalarında da vurgulandığı üzere, bu çalışmalara hizmet öncesi öğretmen eğitiminde başlamak gerekmektedir. Öğretmen adaylarının etken bir öğretmen olarak yetiştirilmeleri son derece önemlidir ve bunun için hizmet öncesi öğretmen eğitiminin en başından itibaren bu duruma özen gösterilmelidir (Soini vd., 2015) çünkü öğrencilerin bu süreçte öğrendikleri ve geçirdikleri deneyimler onların öğretmen kimliklerini etkilemektedir (Ahonen vd., 2015). Yapılan çalışmalarda öğretmen adaylarının akranları ve öğretim üyeleri ile aralarında oluşan güven ve destek deneyimleri, öğretmen adaylarının hizmet öncesi öğretmenlik eğitimi sürecinde tercihte bulunma, etki bırakma ya da sürece aktif bir şekilde katılma vb. firsatlara sahip olması, öğrenme ortamlarının öğretmen adayları ve öğretim üyeleri ile müşterek bir şekilde oluşturulması ve bu kapsamda öğretim üyelerinin öğretmen adayları ile otoritelerini paylaşmaları gibi unsurların öğretmen etkenliğinin artırılmasında etkili olduğu ortaya koyulmuştur (Juutilainen, Metsäpelto ve Poikkeus, 2018).

Hizmet öncesi öğretmen eğitiminde eğitim fakültelerinde öğretim üyeleri öğretmen adaylarının okul kültürüne hazırlanmaları için öğretmen kimliği gelişimine özellikle dikkat ederek adaylarda öğretmen etkenliğini geliştirmelidir. Öğretmen etkenliği gelişim odaklı zihin yapısı (growth mindset) gerektirdiğinden eğitim fakültelerindeki öğretim üyeleri derslerinde ve öğretmenlik uygulamalarında bunu öğretmen adaylarına modellemelidirler (Allen, 2018). Hem hizmet öncesi öğretmen eğitiminde hem de hizmet içi öğretmen eğitiminde bilgi, beceri, inanç ve değer gibi kaynak geliştirme ve yansıtıcı etkileşime odaklanılmalıdır ve mesleki gelişim programlarında okul hakkında alışılageldik ve toplum tarafindan empoze edilen düşünme şekilleri sorgulanmalı ve yansıtıcı bir düşünce yapısı teşvik edilmelidir (Priestley vd. 2015).

Öğretmen etkenliği kavramının önemi her ne kadar alan yazında vurgulanmış olsa da öğretmenlerde etkenliğin gelişimine dair görgül araştırmalar yeterince bulunmamaktadır (Oolbekkink-Marchand vd., 2017). Özellikle Türkiye'de bu kavramı temel alan araştırmaların son derece sınırlı olduğu görülmektedir. Türkiye'de eğitimin niteliği konusunda yapılan tartışmalar çoğunlukla eğitim sistemi, kademeler arası geçiş yöntemleri, eğitim materyalleri gibi konulara odaklanmaktadır. Ancak eğitim kalitesinin en önemli faktörünün öğretmenler olduğu unutulmamalıdır. Öğretmenlerin eylemlerini etkileyen en önemli faktör ise onların kimlikleridir. Bu nedenle öğretmen kimliğine ve onun bir parçası olan öğretmen etkenliğine odaklanılması sorunların çözümü noktasinda yol gösterici olabilir. 


\section{Kaynakça}

Ahonen, E., Pyhältö, K., Pietarinen, J. ve Soini, T. (2015). Student teachers' key learning experiences - mapping the steps for becoming a professional teacher. International Journal of Higher Education, 4(1), 151165. DOI: $10.5430 /$ ijhe.v4n $1 \mathrm{p} 151$

Allen, L.Q. (2018). Teacher leadership and the advancement of teacher agency. Foreign Language Annals, 51, 240-250. https://doi.org/10.1111/flan.12311

Alvunger, D. (2018). Teachers' curriculum agency in teaching a standardsbased curriculum. The Curriculum Journal. DOI: 10.1080/09585176.2018.1486721

Anwuruddin, S.M. (2017). Methodism versus teacher agency in TESOL. D.J. Rivers ve K. Zotzmann (Ed) Isms in language education: Oppression, intersectionality and emancipation içinde. Berlin: De Gruyter.

Ataş Akdemir, Ö. ve Akdemir, A.S. (2019). Öğretmen aktörlüğü: Mesleki gelişimde yeni bir eğilim. Atatürk Üniversitesi Sosyal Bilimler Enstitüsü Dergisi, 23(2), 865-874.

Ayan, M. (2020). Burası tamamen bizim: Öğretmenin özne olma hali, mesleki öğrenme topluluklarl ve öğretmen

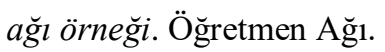

Ball, S.J. (2003). The teacher's soul and the terrors of performativity. Journal of Education Policy, 18, 215-228.

Beauchamp, C., \& Thomas, L. (2009). Understanding teacher identity: An overview of issues in the literature and implications for teacher education. Cambridge Journal of Education, 39(2), 175-189. DOI: 10.1080/03057640902902252

Bellibaş, Ş., Çalışkan, Ö. ve Gümüş, S. (2019). Öğretmen failliği ölçeği’nin (ÖFÖ) geçerlik ve güvenirlik çalışması. Trakya Eğitim Dergisi, 9(1), 1-11. Doi: 10.24315/trkefd.406391

Beijaard, D., Meijer, P., \& Verloop, N. (2004). Reconsidering research on teachers' professional identity. Teaching and Teacher Education, 20, 107-128.

Biesta, G.J.J. (2004). Education, accountability and the ethical demand. Can the democratic potential of accountability be regained? Educational Theory, 54, 233-250.

Biesta, G., Priestley, M. ve Robinson, S. (2015). The role of beliefs in teacher agency. Teachers and Teaching, 21(6), 624-640. DOI: 10.1080/13540602.2015.1044325

Biesta, G. ve Tedder, M. (2007). Agency and learning in the lifecourse: Towards an ecological perspective. Studies in the Education of Adults, 39(2). https://doi.org/10.1080/02660830.2007.11661545

Buchanan, R. (2015). Teacher identity and agency in an era of accountability. Teachers and Teaching, 21(6), 700-719.

Calvert, L. (2016). Moving from compliance to agency: What teachers need to make professional learning work. Oxford, OH: Learning Forward and NCTAF.

Darling-Hammond, L. (1997). The quality of teaching matters most.Journal of Staff Development, 18(1), 38-41.

Doyle, W. (1992). Curriculum and pedagogy. P.W. Jackson (Ed.), Handbook of research on curriculum (ss. 486-516) içinde. Macmillan.

Emirbayer, M., ve Mische, A. (1998). What is agency? American Journal of Sociology, 103, 962-1023.

Erdem, C. ve Eğmir, E. (2018). Öğretmen etkinliği kavramı ve öğretmen etkinliğinin Türk eğitim sistemindeki yeri. II. International Congress on Science and Education, 28-30 Eylül, 2018, Afyonkarahisar, Türkiye.

Fu, G. ve Clarke, A. (2017). Teacher agency in the Canadian context: Linking the how and the what. Journal of Education for Teaching, 43(5), 581-593. https://doi.org/10.1080/02607476.2017.1355046

Fullan, M. G. 1993. Why Teachers must Become Change Agents. Educational Leadership, 50 (6): 12-17.

Giddens, A. (1984). The constitution of society: Outline of the theory of structuration. Berkeley: University of California Press.

Hallinger, P., Liu, S. ve Piyaman, P. (2017). Does principal leadership make a difference in teacher professional learning? A comparative study China and Thailand. Compare: A Journal of Comparative and International Education, 49(3), 341-357. https://doi.org/10.1080/03057925.2017.1407237

Henson, K.T. (1995). Curriculum development for education reform. Harper Collins College Publishers.

Hökkä, P., Eteläpelto, A. ve Rasku-Puttonen, H. (2012). The professional agency of teacher educators amid academic discourses. Journal of Education for Teaching, 38(1), 83e102.

Jenkins, G. (2019). Teacher agency: The effects of active and passive responses to curriculum change. The Australian Education Researcher. https://doi.org/10.1007/s13384-019-00334-2 
Juutilainen, M., Metsäpelto, R-L. ve Poikkeus, A-M. (2018). Becoming agentic teachers: Experiences of the home group approach as a resource for supporting teacher students' agency. Teaching and Teacher Education, 76, 116-125. https://doi.org/10.1016/j.tate.2018.08.013

Kayi-Aydar, H. (2015). Teacher agency, positioning, and English language learners: Voices of pre-service classroom teachers. Teaching and Teacher Education, 45, 94-103.

Kavcar, C. (1987). Türk dili ve edebiyatı öğretimi. Ankara Üniversitesi Eğitim Bilimleri Fakültesi Dergisi, 20(1), 261-273.

Keddie, A., Mills, M. ve Pendergast, D. (2011). Fabricating and identity in neo-liberal times: performing schooling as 'number one'. Oxford Review of Education, 37, 75-92.

Ketelaar, E., Beijaard, D., Boshuizen, H.P.A. ve Den Brok, P.J. (2012). Teachers' positioning towards an educational innovation in the light of ownership, sense-making and agency. Teaching and Teacher Education, 28, 273-282. doi:10.1016/j.tate.2011.10.004

Kuiper, W., Nieveen, N. ve Berkvens, J. (2013). Curriculum regulation and freedom in the Netherlands- A puzzling paradox. W.Kuiper ve J. Berkvens (eds.), Balancing curriculum regulation and freedom across Europe, CIDREE Yearbook 2013 (ss.139-162) içinde. SLO.

Lai, C., Li, Z. ve Gong, Y. (2016). Teacher agency and professional learning in cross-cultural teaching contexts: Pre-service Chinese teachers from international schools in Hong Kong. Teaching and Teacher Education, 54, 12-21.

Lasky, S. (2005). A sociocultural approach to understanding teacher identity, agency and professional vulnerability in a context of secondary school reform. Teaching and Teacher Education, 21, 899-916. doi:10.1016/j.tate.2005.06.003

Lipponen, L., \& Kumpulainen, K. (2011). Acting as accountable authors: Creating interactional spaces for agency work in teacher education. Teaching and Teacher Education, 27(5), 812-819.

Mifsud, D. (2018). Professional identities in initial teacher education: The narratives and questions of teacher agency. Palgrave Macmillan. https://doi.org/10.1007/978-3-319-76174-9

Mutlu, G. (2017). Professional space and agency: The case of in-service language teachers. Journal of Teacher Education and Educators, 6(2), 157-176.

Oolbekkink-Marchand, H.W., Hadar, L.L., Smith, K., Helleve, I. ve Ulvik, M. (2017). Teachers' perceived professional space and their agency. Teaching and Teacher Education, 62,37-46. http://dx.doi.org/10.1016/j.tate.2016.11.005

Pantic, N. (2017). An explanatory study of teacher agency for social justice. Teaching and Teacher Education, 66, 219-230. http://dx.doi.org/10.1016/j.tate.2017.04.008

Parkison, P. (2008). Space for performing teacher identity: Through the lens of Kafka and Hegel. Teachers and Teaching: Theory and Practice, 14, 51-60.

Paris, C. ve Lung, P. (2008). Agency and child-centered practices in novice teachers: Autonomy, efficacy, intentionality, and reflectivity. Journal of Early Childhood Teacher Education, 29(3), 253-268. https://doi.org/10.1080/10901020802275302

Philpott, C. (2017). Teacher agency and professional learning communities: What can learning rounds in Scotland teach us? M.A. Peters, B. Cowie ve I. Menter (Ed.) A companion to research in teacher education içinde. Springer.

Priestley, M., Biesta, G.J.J. \& Robinson, S. (2015). Teacher agency: what is it and why does it matter? In R. Kneyber \& J. Evers (eds.), Flip the System: Changing Education from the Bottom Up. Routledge.

Priestley, M., Biesta, G.J.J. \& Robinson, S. (2015). Teacher agency: An ecological approach. Bloomsburry.

Pyhältö, K., Pietarinen, J. ve Soini, T. (2012). Do comprehensive school teachers perceive themselves as active professional agents in school reforms? Journal of Educational Change, 13(1), 95-116.

Ray, J.M. (2009). A template analysis of teacher agency at an academically successful dual language school. Journal of Advanced Academics, 21(1), 110-141.

Riveros, A., Newron, P. ve Burgess, D. (2012). A situated acoount of teacher agency and learning: Critical reflections on professional learning communities. Canadian Journal of Education, 35(1), 202-216.

Rogers, R. ve Wetzel, M. M. (2013). Studying agency in literacy teacher education: A layered approach to positive discourse analysis. Critical Inquiry in Language Studies, 10(1), 62-92. 
Sahlberg, P. (2010). Rethinking accountability in a knowledge society. Journal of Educational Change, 11, 4561.

Sannino, A. (2010). Teachers' talk of experiencing: Conflict, resistance and agency. Teaching and Teacher Education, 26, 838-844. https://doi.org/10.1080/10901020802275302

Sloan, K. (2006). Teacher identity and agency in school worlds: Beyond the all-good/all-bad discourse on accountability-explicit curriculum policies. Curriculum Inquiry, 36(2), 119-152. https://doi.org/10.1111/j.1467-873X.2006.00350.x

Soini, T., Pietarinen, J., Toom, A. ve Pyhältö, K. (2015). What contributes to first-year student teachers' sense of professional agency in the classroom. Teachers and Teaching, 21(6), 641-659. DOI: $10.1080 / 13540602.2015 .1044326$

Taba, H. (1962). Curriculum development: Theory and practice. New York: Harcourt, Brace \& World, Inc.

Tao, J. ve Gao, X. (2017). Teacher agency and identity commitment in curricular reform. Teaching and Teacher Education, 63, 346-355. http://dx.doi.org/10.1016/j.tate.2017.01.010

Toom, A., Pietarinen, J., Soini, T. ve Pyhaltö, K. (2017). How does the learning environment in teacher education cultivate first year student teachers' sense of professional agency in the professional community? Teaching and Teacher Education, 63, 126-136.

Toom, A., Pyhaltö, K., \& Rust, F. O. (2015). Teachers' professional agency in contradictory times. Teachers and Teaching, 21(6), 615e623.

Vahasantanen, K. (2015). Professional agency in the stream of change: Understanding educational change and teachers' professional identities. Teaching and Teacher Education, 47, 1-12.

Verberg, C.P.M., Tigelaar, D.E.H., van Veen, K. ve Verloop, N. (2016). Teacher agency within the context of formative teacher assessment: An in-depth analysis. Educational Studies, 42(5), 534-552. https://doi.org/10.1080/03055698.2016.1231060

Villegas, A. M., ve Lucas, T. (2002). Educating culturally responsive teachers. State University of New York Press.

Volkmann, M.J., \& Anderson, M.A. (1998). Creating professional identity: Dilemmas and metaphors of a firstyear chemistry teacher. Science Education, 82(3), 293-310. 